\title{
Ciudades vettonas
}

\author{
Vettonian cities
}

\author{
Jesús Álvarez-SANChís
}

Departamento de Prehistoria. Universidad Complutense, 28040-Madrid

jralvare@ghis.ucm.es

Recibido: 26-11-2010

Aceptado: 18-02-2011

\section{RESUMEN}

La emergencia de grandes centros fortificados conocidos como oppida, a finales de la Edad del Hierro en la Iberia Céltica, es un fenómeno que empieza a ser mejor conocido. Como en otras regiones de la Europa Templada, probablemente existían diferencias muy sustanciales entre ellos, y diferian en tamaño, forma, función y cronología. De algunos pequeños asentamientos se conocen los primeros momentos de instalación, pero la evolución de estas comunidades en otras más grandes y complejas no está clara. Una cuestión básica es la de si la ciudad responde a un proceso de evolución interna o a un cambio en el modelo de sociedad impuesto por Roma. En este trabajo se abordan las relaciones entre oppida, cultura material y etnicidad en el ámbito de los vettones, una de las poblaciones prerromanas del oeste peninsular. La interpretación sociológica de los cementerios y los patrones de asentamiento regional ofrecen una visión interesante sobre el modelo de organización social de estas comunidades entre los siglos IV y I a.C.

Palabras Clave: Vettones. Identidad. Meseta. Edad del Hierro. Oppidum. Conquista Romana.

\begin{abstract}
The emergence of large fortified settlements, known as oppida, in "Celtic" Iberia during the Late Iron Age, is a process which begins to be known with more accuracy. As in other areas of temperate Europe, there were probably substantial differences between them, in terms of geographical setting, size, form, function and chronology. We know when some small settlements were founded, but the evolution of these communities into other ones that were somewhat larger and more complex is not clear. A basic question is whether the city grew in response to an internal process of evolution or to a changed model of society imposed by Rome. The exploration of the relationships between oppida, material culture and ethnicity is considered in this paper for the Vettones, one of the pre-Roman peoples in Western Spain. It is argued that the sociological interpretation of the cemeteries and the regional patterns of settlement offer interesting insights into the model of social organization of the indigenous societies between the fourth and first centuries $B C$.
\end{abstract}

KeY words: Vettones. Identity. Meseta. Iron Age. Oppidum. Roman Conquest.

Sumario: 1. La ocupación del territorio en la Edad del Hierro y la información disponible. 2. Hacia la formación de los oppida (c. 400-200 a.C.): los estímulos internos. 3. Hacia la formación de los oppida (c. 200-50 a.C.): los estímulos externos. 
Hace 2500 años la Meseta española era un mosaico de pequeños pueblos, granjas y aldeas. La vida cotidiana de la inmensa mayoría de sus gentes giraba en torno a las tareas del campo y del hogar. Apenas conocemos con exactitud el alcance de los contactos mantenidos entre ellas, pero lo cierto es que las comunidades asentadas en las sierras y penillanuras occidentales, es decir, en el territorio que actualmente abarcan las provincias de Ávila y Salamanca, así como una parte de Zamora, Toledo y Cáceres, compartieron en ese momento una serie de rasgos culturales -organización social y económica, elementos materiales, lengua, y probablemente también ideas y creencias religiosas- hasta el punto de que esa identidad fue posteriormente reconocida por los escritores romanos con el nombre de Vettonia (Fig. 1). Ese mundo de la Edad del Hierro constituye la base demográfica de donde emergen los oppida, las primeras ciudades de tipo urbano con poblaciones de varios cientos o miles de personas (Collis 1984; Buchsenschutz 1988; Fichtl 2005). E1 tema tiene un gran interés, entre otras causas porque con estos centros se produce la primera organización compleja del territorio, la primera ordenación socio-política del paisaje que va más allá de los poblados autárquicos conocidos siglos atrás (Collis 2000; Haselgrove 2006).

¿Significa todo eso que las ciudades vettonas no existieron antes? De algunos pequeños asentamientos se conocen los primeros momentos de instalación, pero la evolución de estas comunidades hacia otras más grandes y complejas no está clara. Una cuestión básica, porque es previa al planteamiento de todo este esquema, es la de si la ciudad responde a un proceso de evolución interna o a un cambio en el modelo de sociedad impuesto por Roma. Dicho de otro modo: ¿Las ciudades vettonas se fundaron en los dos siglos previos al cambio de Era, por tanto en tiempos de la conquista romana, o son el resultado del desarrollo en el tiempo de pequeñas granjas y aldeas, y de la capacidad de alguna de ellas de controlar un territorio mayor y más jerarquizado? Empezaremos por una valoración de la evidencia que se ha descubierto.

\section{La ocupación del territorio en la Edad del Hierro y la información disponible}

Los siglos inmediatos al año 1000 a.C. fueron tiempos de profundos cambios en las regiones del interior de la Península Ibérica. Existieron más y mayores asentamientos en este período que en cualquiera de los precedentes, y por primera vez muchos fueron ocupados durante varios cientos de años en lugar de sólo por un par de generaciones. La emergencia de aldeas fortificadas en cerros y colinas de fácil defensa, controlando el territorio circundante y albergando en su interior a pequeños grupos de familias, fue un episodio extraordinariamente importante. Este proceso resulta comparable con el fenómeno, más o menos coetáneo en Europa, de los hillforts en las Islas Británicas (Cunliffe 1990 y 1994) y las ciudadelas principescas al norte del arco alpino, esto es, las famosas Fürstensitze de Alemania, Suiza, Francia y Austria (Brun 1987). Que las personas pudieran sobrevivir más tiempo en un mismo sitio implica el conocimiento que éstas tenían de las técnicas que mejoran y preservan la fertilidad de los suelos, como puede ser el policultivo, la rotación de cereales y leguminosas, el uso del arado ligero o la utilización de abonos (Ruiz-Gálvez 1992; Sherrat 1993). Todos estos cambios trajeron consigo la estabilidad de las poblaciones sobre la tierra y las parcelas de cultivo (Bradley y Yates 2007; Blanco 2010a y 2011).

La información que tenemos en este momento para el oeste de la Meseta y el valle del Duero es bastante desigual. Las excavaciones en extensión en el interior de los asentamientos son escasas y por lo tanto conocemos bastante mal la anatomía interna de estos hábitats, tanto de los que son simples poblados como de aquellos que pudieron tener una función militar o comercial específica. Así y todo, los sitios que fueron habitados en la época ofrecían en líneas generales las siguientes características:

(1) Superficies pequeñas, entre 0,2 y 5 hectáreas, siendo excepcionales áreas más grandes. Podrían albergar una población que oscilaría entre varias decenas de habitantes y excepcionalmente unos pocos centenares. 
(2) Una organización interna simple con viviendas junto a la muralla, o bien grupos de casas con paredes medianiles comunes formando pequeñas manzanas que delimitarían a su vez pequeñas calles. En los casos más sencillos simples cabañas circulares de adobe o tapial, en ocasiones sobre cimentación de piedras de granito, que se distribuirían sin ordenamiento aparente.

(3) Algunos de estos sitios estaban defendidos con troncos y empalizadas de madera; otros construyeron murallas de piedra, fosos y estacas hincadas en el suelo para dificultar los ataques de poblaciones hostiles. Pero la inmensa mayoría, no lo olvidemos, vivía básicamente en pequeñas granjas y alquerías sin ninguna intención defensiva.

Entre finales del siglo VI a.C. y el siglo IV a.C. los asentamientos y centros de riqueza más importantes fueron abandonados en su mayoría y el sistema de poblamiento evolucionó hacia formas de mayor complejidad (Álvarez-Sanchís 2005; Esparza y Blanco 2008). Sin duda alguna el fenómeno más importante fue la emergencia de nuevas aldeas fortificadas -más grandes que las anteriores- que se extendieron por buena parte de la geografía de la Meseta. Sus gentes se enterraron en necrópolis de incineración y se acompañaron de ajuares que incluían un pequeño pero significativo porcentaje de armas. Fueron los protagonistas principales de este período hasta la disolución de los sistemas de poblamiento tras la conquista romana.

En el centro de la provincia de Ávila hay que destacar una importante ocupación humana, con contrastes muy significativos en los modelos de asentamiento (Álvarez-Sanchís 1999: 104). En concreto en el valle Amblés puede hablarse de dos zonas de distribución de yacimientos, por un lado los rebordes montañosos que circundan el valle, erizados de rocas graníticas, con buenos recursos ganaderos y que agrupan a la mayor parte de los castros fortificados: Las Cogotas (Cardeñosa), La Mesa de Miranda (Chamartín), Ulaca (Solosancho) y Sanchorreja. Por otro, las zonas llanas próximas a la vega del río Adaja, ocupadas por yacimientos no amurallados y de

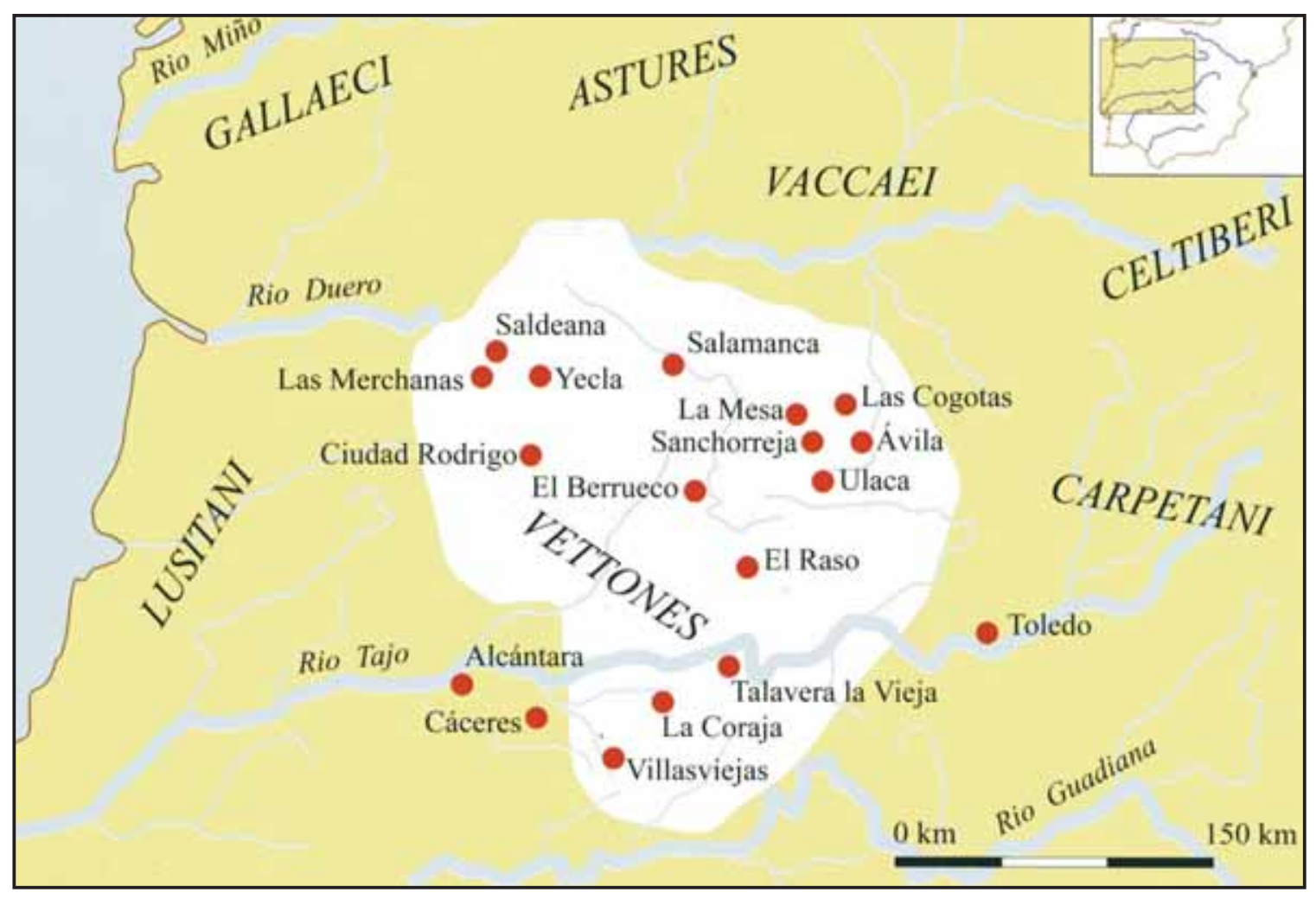

Figura 1.- Límites geográficos de los vettones según las fuentes y localización de los principales yacimientos citados en el texto (Álvarez-Sanchís 2003). 
escasa entidad. Hacia este mismo momento diversas ocupaciones se distribuyen al sur de Gredos y en torno al Tiétar: castros de Escarabajosa (Sta. María del Tiétar), Berrocal (Arenas de San Pedro) y Castillejo de Chilla (Candeleda). Una parte de los asentamientos de la Primera Edad del Hierro fueron abandonados en el transcurso de los siglos V-IV a.C. (Fabián 1999). Algunas cerámicas y objetos de bronce dan pie a sospechar de la existencia de una ocupación humana de esa época en Las Cogotas (Álvarez-Sanchís 1999: 74 ss.; Blanco 2010b) y en los alrededores de El Raso (Candeleda) (Fernández Gómez 1995 y 1997), pero los poblados que paulatinamente emergen desde el siglo IV a.C. en adelante son, en su inmensa mayoría, hábitats de nueva planta.

La evidencia que tenemos en el valle del Tajo también nos depara importantes novedades. Sólo unos pocos emplazamientos, casi siempre junto a los vados del río -Arroyo Manzanas (Las Herencias), El Carpio (Belvís de la Jara), Calera de Fuentidueña (Azután), Cerro de La Mesa (Alcolea de Tajo), Talavera la Vieja- ofrecen una amplia secuencia de ocupación, desde el Bronce Final/Primera Edad del Hierro hasta la conquista romana (Chapa y Pereira 2006; Álvarez-Sanchís 2007a; Charro y Cabrera 2011). Los sitios localizados se ubican en alto y en llano, en cerros inmediatos a la vega y, aunque no se puede afirmar rotundamente, una gran parte pudo haber contado con murallas en un momento determinado de su existencia. La abundancia de tierras de cultivo debió ser uno de los factores más positivos en la localización de estos asentamientos (Carrobles 2009). Si ampliamos la lectura al oeste de la provincia de Cáceres, vemos de nuevo una ocupación en torno a los ríos: Castillejo de la Orden (Alcántara), La Muralla (Alcántara), Sansueña (Cáceres) o El Zamarril (Portaje). Aquí, por el contrario, las estimaciones que se han realizado sobre los recursos potenciales nos hablan de un entorno muy favorable para el aprovechamiento ganadero (Martín Bravo 1999: 201 ss. y 2009). Hay que reconocer que los modelos de asentamiento en esta época eran todavía relativamente modestos en cuanto a envergadura y escala.

Los asentamientos inmediatos al valle del río Tormes -cerro de San Vicente (Salamanca), Ledesma o Las Paredejas, al pie del Berrueco
(Medinilla) ....- no albergan ninguna duda sobre la continuidad del poblamiento, al menos desde el siglo VII a.C. en adelante (Martín Valls et al. 1991; Benet et al. 1991; Fabián 2005a). En las penillanuras occidentales de Salamanca -El Picón de la Mora, Las Merchanas, Yecla- las evidencias son todavía demasiado tenues para esa época. Hay que reconocer que faltan excavaciones y estratigrafías (Benet y López Jiménez 2008), y seguramente el desarrollo "urbano" de los castros pudo haber influido en el arrasamiento de estructuras más endebles características del período anterior. En cualquier caso, el apogeo del mundo castreño en esta parte de la provincia ha de llevarse a la Segunda Edad del Hierro (Martín Valls 1999; Martín Valls y Romero 2008). Ahora es cuando, junto a los castros citados, se desarrollan Irueña, La Plaza de Gallegos de Argañán, Saldeana, Los Castillos de Gema... Hasta qué punto la emergencia y el desarrollo de estos sitios se relaciona con la riqueza minera de la comarca es algo que queda aún por dilucidar, pero lo cierto es que los asentamientos ofrecen un patrón muy singular, con núcleos poderosamente fortificados y un significativo nivel de concentración que desentona del resto.

Como puede verse, la evidencia arqueológica en la Meseta occidental ofrece situaciones bastante desiguales entre unas comarcas y otras, pero desde el punto de vista de los patrones de asentamiento hay una coincidencia muy sustancial: el número de poblados conocido denota inequívocamente un crecimiento demográfico y las continuidades respecto a la fase anterior testimonian una progresiva identificación entre las gentes y el territorio (Fig. 2). No estamos en condiciones de discriminar cuantitativamente todo este proceso, pero lo cierto es que entre el $65 \%$ y el $75 \%$ de los yacimientos conocidos son de nueva planta (Álvarez-Sanchís 1999: 104107). Para fundar una aldea y para que ésta sea estable es necesario invertir un tiempo mínimo - unas pocas generaciones- sobre todo cuando el control del territorio está todavía por consolidar (Jimeno 2000: 243). Este desarrollo debió ser gradual, seguramente más importante en las últimas centurias. Por ejemplo, los asentamientos celtibéricos que se conocen en el Alto Duero ofrecen valores aproximados de 2 a 1 y de 3 a 1 para núcleos de nueva planta en los siglos IV-III a.C. y II-I a.C. respectivamente (Jimeno 
(a) Occidente de Salamanca

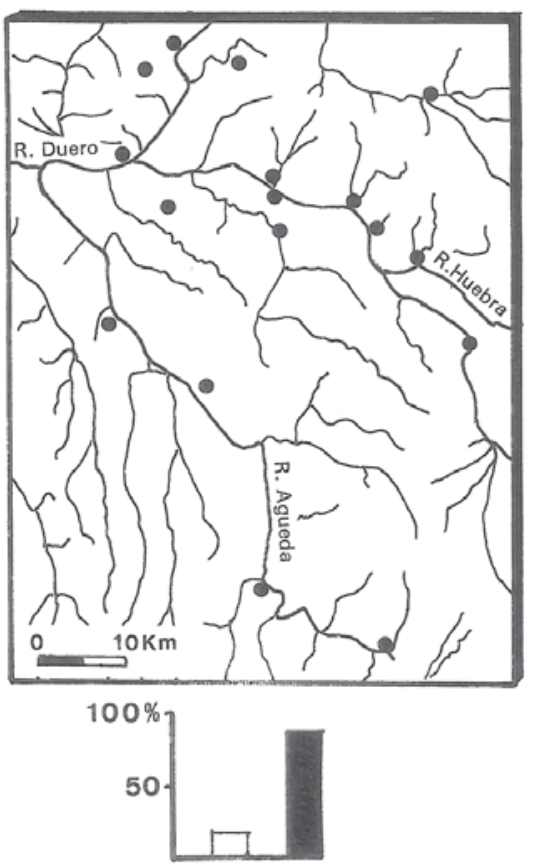

(b) Valle Amblés

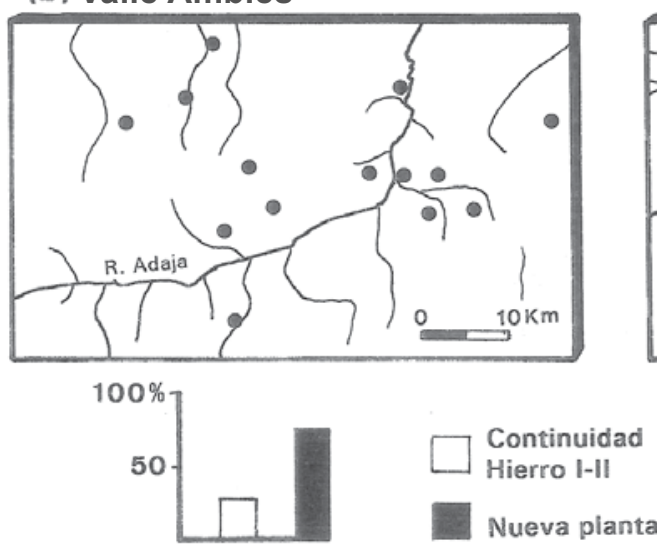

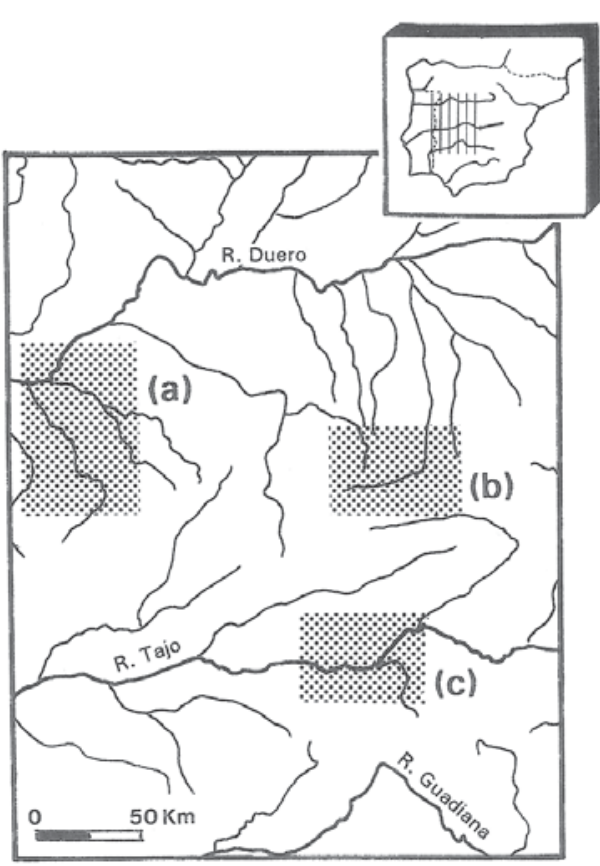

(c) Tajo Medio
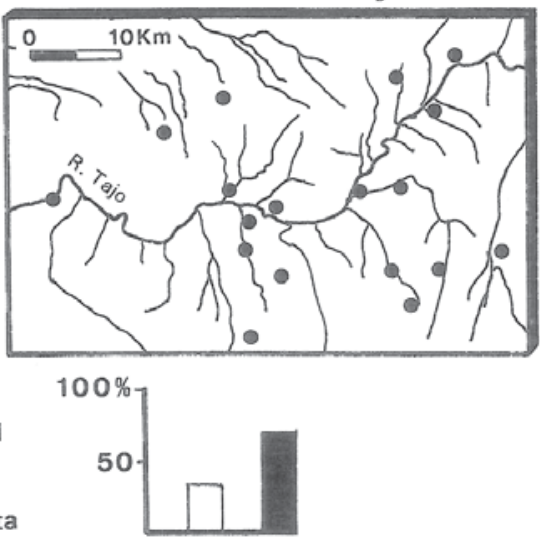

Figura 2.- Diagrama-resumen del poblamiento vettón. Porcentajes de continuidad entre los asentamientos del Hierro I y del Hierro II, y del hábitat de nueva planta en la Segunda Edad del Hierro (Álvarez-Sanchís 1999).

y Arlegui 1995: 108-109). La datación concreta de una parte de los asentamientos vettones puede resultar todavía prematura dada la falta de excavaciones para referenciar los materiales hallados en prospección, pero simultaneando lo conocido en el valle medio del Duero (San Miguel 1993: 31 ss.; Sacristán et al. 1995) y en la región extremeña (Ortiz y Rodríguez Díaz 1998: 258), el diagnóstico es también favorable. Todo ello implica un crecimiento, no sólo en cuanto al número de habitantes, sino también en lo que se refiere al desenvolvimiento de las actividades económicas, más diversificado, como se infiere de los modelos de asentamiento. La fabricación de aperos e instrumentos de hierro y la explotación de nuevas zonas para producir alimentos facilitaron la ampliación del terrazgo. Estas evidencias no deben ser vistas desde una perspectiva exclusivamente tecnológica. Hay que suponer que estamos asistiendo a una profunda reorientación del uso de la tierra y de sus excedentes, lo que habría exigido un considerable esfuerzo comunitario, seguramente organizado bajo las directrices de alguna forma de autoridad (Álvarez-Sanchís 2003a: 360-365). Lo cierto es que a partir del siglo IV a.C. la significación de 
estos sitios en el paisaje fue referenciada visualmente con límites, parcelas, murallas, fosos, necrópolis...., y eso contribuyó a reforzar las distinciones entre las gentes que habitaban el territorio. Algunos poblados se abandonaron, pero otros fueron intensamente ocupados, conocieron distintas fases de amurallamiento y llegaron a convertirse a finales de la Edad del Hierro en importantes centros de distribución regional.

\section{Hacia la formación de los oppida (c. 400-200 a.C.): los estímulos internos}

El proceso de transformación de estas comunidades en otras más complejas plantea varias incógnitas (Cunliffe 1994; Ralston 2006). No todos los oppida fueron fundaciones contemporáneas de la conquista romana. Las fuentes clásicas mencionan con frecuencia la existencia de grandes centros indígenas en el siglo II a.C. y esto ya nos está dando una data ante quem para su construcción (Almagro-Gorbea y
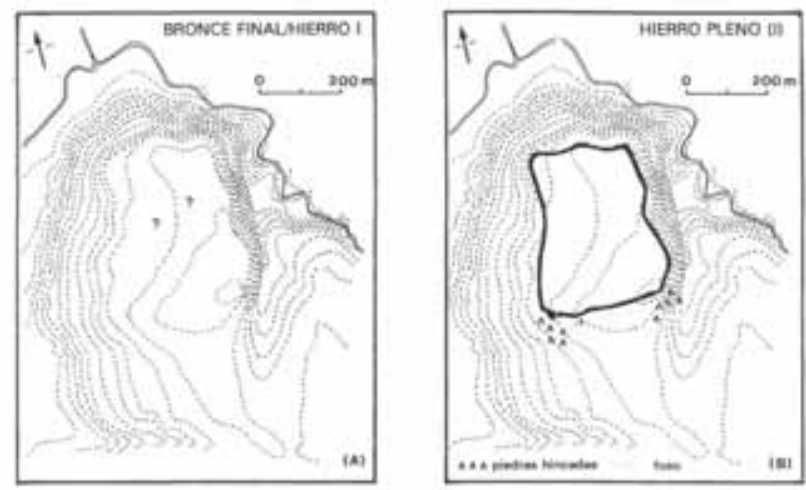

LA MESA DE MIRANDA
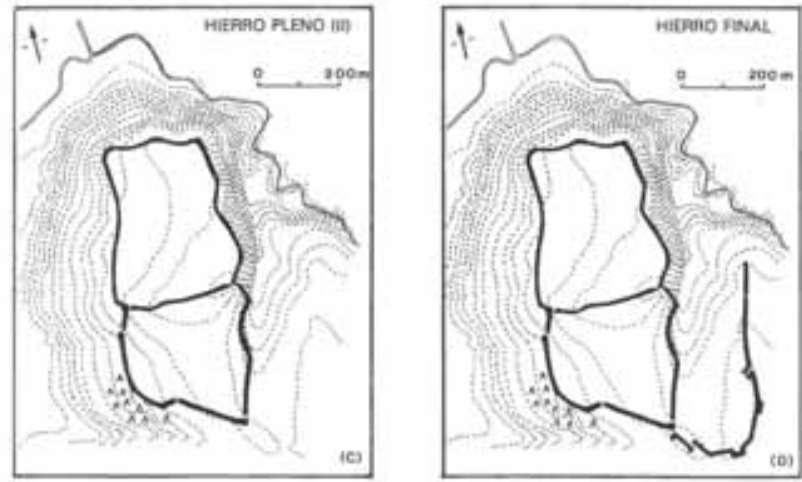

Figura 3.- Fases de ocupación del castro de La Mesa de Miranda (Chamartín, Ávila) (Álvarez-Sanchís 1999).

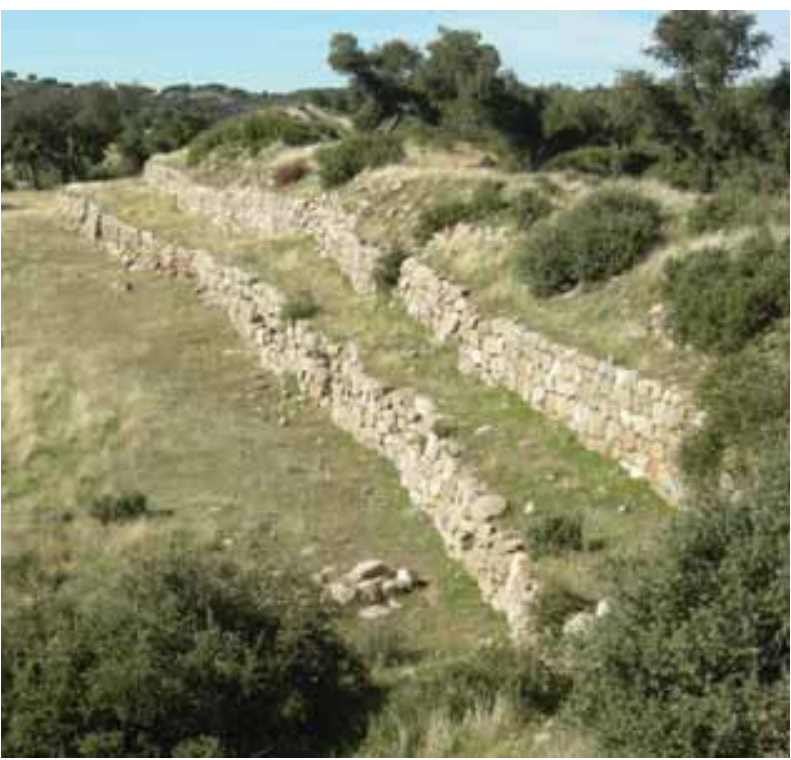

Figura 4.- Foso, muralla y ante muralla sur del primer recinto de La Mesa de Miranda.

Lorrio 1991), por lo que es posible rastrear sus antecedentes desde algo antes. La documentación arqueológica demuestra la existencia de asentamientos que ya eran centros importantes en los siglos IV y III a.C. e implican que el comercio inter-regional ya era un factor básico en la época.

Es muy probable que por estas fechas algunos asentamientos de la provincia de Ávila sufrieran una remodelación importante. La Mesa de Miranda (Chamartín) es un oppidum formado por tres recintos que albergan una superficie de casi 30 ha (Cabré et al. 1950: 15-17). Los dos primeros (19 ha), con foso y piedras hincadas delante de las entradas, flanqueadas a su vez por bastiones, fueron interpretados en su día como zonas residenciales, pero hay que reconocer que la mayor parte de los vestigios se circunscriben sólo al primero (Fabián 2005b; Álvarez-Sanchís 2007b; González-Tablas 2009: 71 ss.). El tercero estaba reforzado con torres de planta cuadrangular y aparejo ciclópeo, bien dispuestas para la defensa de la entrada principal. Sin embargo, las cimentaciones de edificios son virtualmente inexistentes lo que, hasta cierto punto, implicaría que el asentamiento no sólo era una aglomeración de casas y establos (Figs. 3 y 4). En correspondencia con la cronología aportada por los ajuares de la necrópolis, los dos primeros recintos se levantaron en el transcurso de los siglos IV y III a.C. El tercer recinto, con técnica bien 

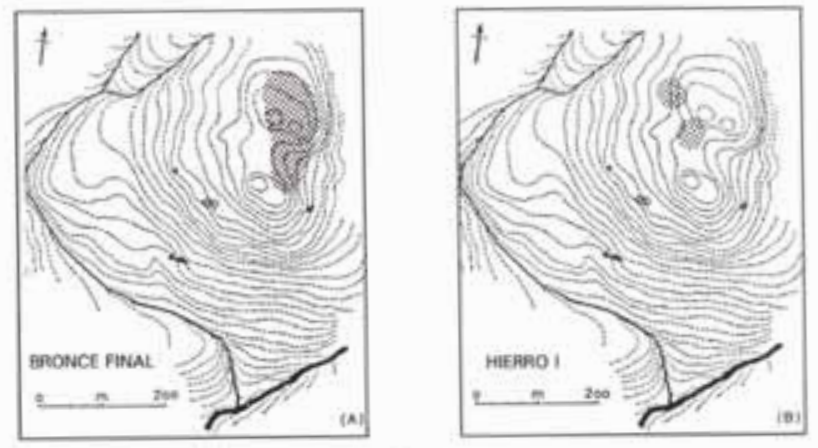

LAS COGOTAS
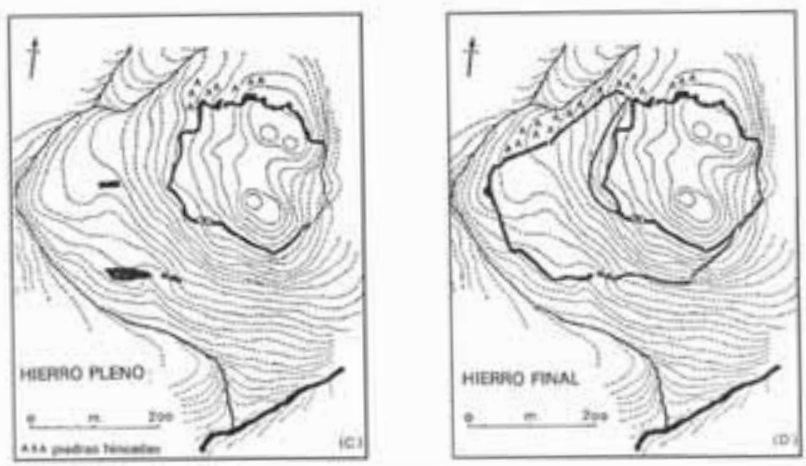

Figura 5.- Fases de ocupación del castro de Las Cogotas (Cardeñosa, Ávila) (Álvarez-Sanchís 1999).

distinta a la empleada en los otros dos, invadía un sector del cementerio. Tal ampliación responde probablemente a un momento de inseguridad (Martín Valls 1986-87: 81-82; Fabián 2005b: 20 ss.), habiendo sido relacionado con las guerras que ocasiona la conquista romana en el transcurso del siglo II a.C.

Cuanto antecede también es válido para Las Cogotas (Cardeñosa), sitio de casi 15 ha formado por dos grandes recintos amurallados con tres entradas cada uno, más compleja y elaborada la principal del recinto superior (Cabré 1930; Ruiz Entrecanales 2005; González-Tablas 2009: 64 ss.). Las excavaciones llevadas a cabo en la zona suroccidental del segundo recinto (Ruiz Zapatero y Álvarez-Sanchís 1995; Álvarez-Sanchís et al. 1998) pusieron al descubierto una superficie con abundante material arqueológico y varias áreas especializadas: un gran basurero colectivo, un pavimento de piedra de compleja interpretación en conexión con la muralla y un alfar o taller destinado a la elaboración de productos cerámicos. Los recipientes hallados en este último -cerámicas a torno de pastas anaranjadas con decoración pintada- se relacionan bien con las produccio- nes vacceas y celtibéricas del siglo II a.C. (Sacristán de Lama 1986; Salas 2008). La estratigrafía obtenida es importante porque aunque el nivel de fundación de la muralla del segundo recinto se corresponde con el nivel constructivo del alfar, la existencia de un cenizal que se encuentra debajo de la primera demuestra que con anterioridad al emplazamiento del taller cerámico y de las defensas ya se estaban desarrollando actividades colectivas en esa zona (Figs. 5 y 6). Por tanto, en la secuencia de ocupación del oppidum pudo haber un primer momento (s. IV-III a.C.) sólo con el recinto superior amurallado y actividades secundarias en la explanada o arrabal situada al suroeste, y un segundo momento (s. II a.C.) en el que se decide amurallar este sector. Lo interesante, en definitiva, es comprobar la toma de decisión para establecer una serie de actividades especializadas e incluirlas dentro del recinto de la ciudad.

El oppidum de Ulaca (Solosancho) es conocido desde antiguo por la monumentalidad de alguna de sus estructuras. Una de ellas, conocida como "Altar de Sacrificios", es una estancia rectangular tallada en la roca $(16 \times 8 \mathrm{~m})$, asociada a una gran peña, en la que una doble escalera conduce a una plataforma con dos concavidades comunicadas entre sí. Una de ellas vertía en una tercera, la cual comunica a su vez con la parte inferior de la peña a través de un canal (Fig. 7). La sacralidad del monumento es posible esta-

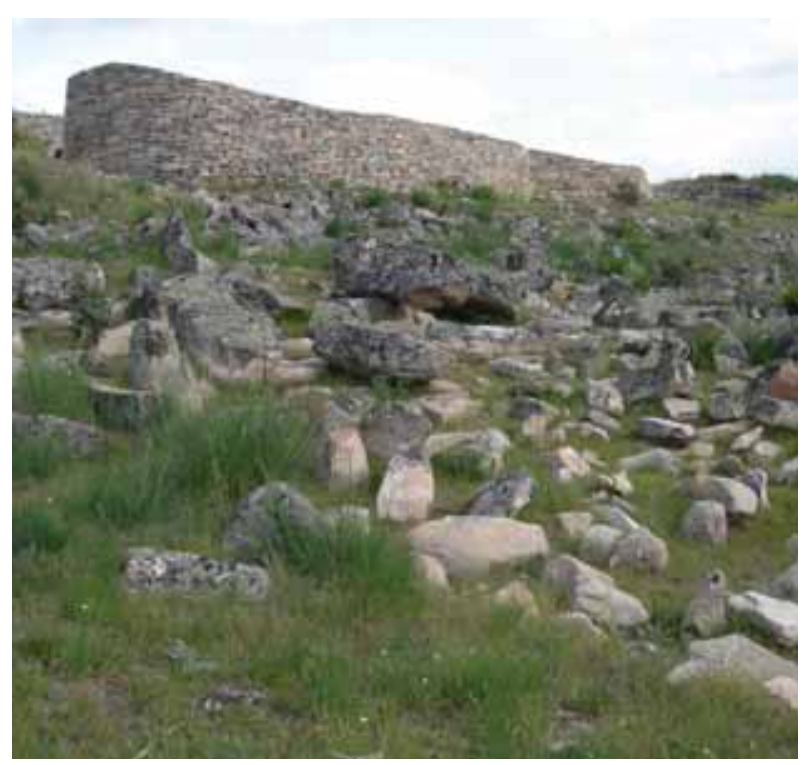

Figura 6.- Barrera defensiva de piedras hincadas y lienzo amurallado principal de Las Cogotas. 


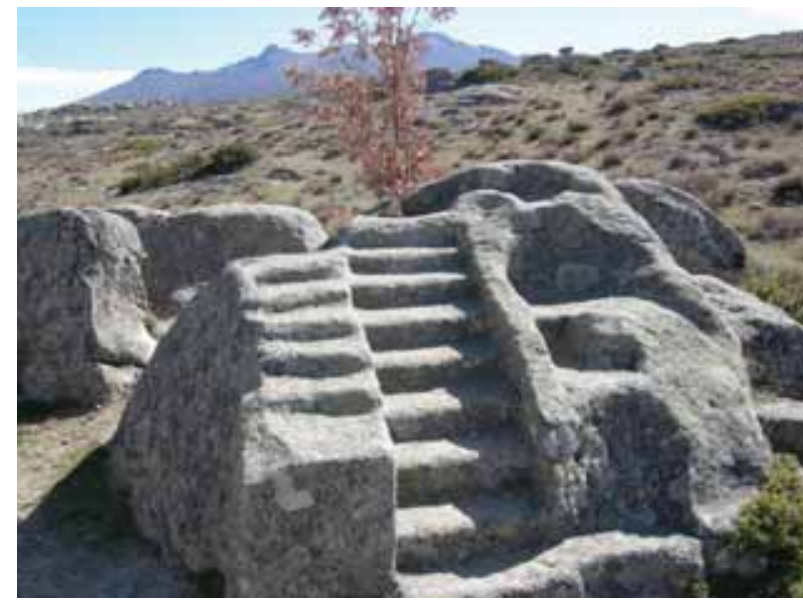

Figura 7.- Altar rupestre de Ulaca (Solosancho, Ávila).

blecerla a partir de una serie de paralelos (Martín Valls 1985: 116-117), el más conocido de los cuales es el santuario portugués de Panoias, asociado a inscripciones latinas que nos informan de los sacrificios realizados (Alföldy 1995; Rodríguez Colmenero 1999). En las inmediaciones del altar se halla otra construcción rupestre de planta rectangular $(6,4 \mathrm{~m})$ dividida en tres habitaciones a modo de antecámara, cámara y horno, para la que se ha propuesto una función termal (Almagro-Gorbea y Álvarez-Sanchís 1993) a partir de los paralelos documentados en las saunas o "pedras formosas" del mundo galaico y lusitano (Ríos González 2000). Su asociación al agua, al vapor y al fuego en lugares hipogeos, así como un conocido texto de Estrabón alusivo al desarrollo de estas actividades entre las poblaciones del Duero, podrían relacionarlo con ritos y baños de carácter iniciático: De algunos de los pueblos que viven en las inmediaciones del Duero se dice que viven a la manera espartana, ungiéndose dos veces con grasas y bañándose de sudor obtenido con piedras candentes, bañándose en agua fría y tomando una vez al día alimentos puros y simples (Estrabón 3,3,6). Parece factible defender la primacía de Ulaca en el territorio, teniendo en cuenta el santuario rupestre, cuya función religiosa debió ser exclusiva en la comarca, y la superficie que encierra el recinto fortificado, por encima de las 70 hectáreas, lo que convierte al oppidum en el centro vettón más importante de la región y en uno de los mayores conocidos (Ruiz Zapatero 2005).

Estos y otros asentamientos vienen proporcionando evidencias de producción agrícola e industrial que demuestran que las manufacturas y la producción de alimentos se harían a una escala nunca alcanzada con anterioridad. Un aspecto muy importante de esta intensificación sería la existencia de un comercio interregional que explicaría el desplazamiento de productos a grandes distancias y la evidencia de especialistas itinerantes. Los ajuares recuperados en las necrópolis de Las Cogotas, El Raso, La Osera -como se conoce tradicionalmente al cementerio de La Mesa de Miranda- y Castillejo de la Orden (Alcántara), han proporcionado distintos tipos de espadas, lanzas y puñales de hierro, además de escudos con umbos metálicos, fíbulas, broches de cinturón, calderos de bronce, cerámicas griegas, cerámicas campanienses y otros recipientes, que demuestran la existencia de contactos intensos en los siglos IV y III a.C. con otras comunidades de la Meseta, Andalucía y el Levante (Baquedano 1996). Este proceso también se detecta en la fabricación de urnas, platos y vasos de ofrendas, con un incremento paulatino de la industria a torno. La producción y el intercambio de productos manufacturados llegó a alcanzar bastante complejidad entre las comunidades vettonas, $\mathrm{y}$, aunque la evidencia disponible no permite asegurarlo, existen indicios que hacen pensar que las bases de subsistencia experimentaron aquellos años un importante crecimiento (Esparza 1999). La obtención de excedentes alimenticios para acceder con facilidad a las redes de intercambio habría conducido a una expansión del sector agropecuario. Estos excedentes favorecerían también el trabajo en los talleres de los oppida y una cierta especialización.

En el área abulense, los centros fortificados parecen ocupar la cumbre de un patrón de poblamiento jerarquizado que tenía por debajo pequeñas aldeas y granjas aisladas. Generalmente estas últimas se asentaban cerca de los ríos, carecían de fortificaciones y sus habitantes debían pasar la mayor parte del tiempo produciendo comida. Desconocemos muchas cosas de estos pequeños sitios. Se trataría del tipo de asentamiento más numeroso y constituiría buena parte del tejido de la población rural (Álvarez-Sanchís y Ruiz Zapatero 2001), pero, como en muchos otros ámbitos, asentamientos de esta categoría apenas se han excavado y el esfuerzo e interés de los arqueólogos 
se ha dirigido a los sitios mayores al resultar más rentables en términos de investigación. En algunos casos, como en el valle Amblés, una aproximación a su diferencia con los oppida se ha tenido en cuenta a partir de dos referentes (Álvarez-Sanchís 1999: 115 ss.). De una parte, el análisis de los territorios de explotación, que en los sitios pequeños revela una fuerte orientación agrícola, entre el $60-80 \%$ en un radio de $2 \mathrm{Km}$, pues se emplazan en el fondo del valle con ricos suelos aluviales. Los territorios de explotación de los oppida revelan por el contrario una orientación básicamente ganadera, si se atiende además a la calidad de sus suelos y a los aún densos mantos de encinas. En Las Cogotas el suelo cultivable en el anillo de 1 hora, considerando la distorsión topográfica, es de apenas algo más de un 15\%. En La Mesa de Miranda los valores son del 20\% mientras en Ulaca el suelo arable apenas rebasa el 30\%. De otra parte, las funciones de los oppida y los pequeños asentamientos. Los primeros se individualizan, entre otras cosas, porque desarrollaron una variedad de actividades industriales -bien documentado en el alfar de Las Cogotas-, estuvieron implicados en redes de intercambio -como evidencian las armas de las necrópolis y algunas importaciones-, estuvieron fuertemente fortificados y construyeron, como en el caso de Ulaca, estructuras monumentales de función cultual. Estos rasgos contrastan con las deducciones que permiten los pequeños asentamientos del llano, con una producción limitada, sin evidencias de contactos a larga distancia y sin estructuras defensivas y religiosas.

El registro arqueológico demuestra que el solar originario de Salamanca fue el cerro de San Vicente (Macarro 1999). Su tamaño apenas rondaba la hectárea y media a comienzos de la Edad del Hierro, pero en el siglo IV a.C. se extiende hasta la colina inmediata (Las Catedrales), como ponen de manifiesto los hallazgos de cerámica a peine y acanalada en las excavaciones realizadas en este último sitio, alcanzando entonces una superficie en torno a las veinte hectáreas (Martín Valls et al. 1991; Alario y Macarro 2007). De la toma de Helmantiké por el cartaginés Aníbal en la primavera del año 220 a.C. (Bejarano 1955), merecen destacarse varios datos. De un lado, la definición que se hace de este núcleo en las fuentes clásicas como "ciudad grande" o "ciudad grande de Iberia" (Polieno, 7,48; Plutarco, mul. uirt.); de otro, los sucesos que se narran durante su conquista, en concreto la mención de Plutarco a propósito de una zona extramuros o barrio apartado del centro principal, con lo que hay que suponer un emplazamiento relativamente extenso y diferenciado; por último, la cita de Tito Livio $(21,5)$, cuando señala que la ciudad fue tomada por asalto, de donde se deduce la presencia de un conjunto fortificado, hecho parcialmente constatado si tenemos en cuenta que en el teso de las Catedrales se halló la cimentación de una muralla construida con grandes bloques de granito en seco, de unos cuatro metros y medio de anchura, sobre el que apoyaba un nivel arqueológico con materiales bien fechados en la Segunda Edad del Hierro (Martín Valls 1999: 215). Trabajos más recientes han deparado los restos de un cubo defensivo de planta circular, magníficamente conservado, que se ha relacionado con una de las puertas monumentales del antiguo castro (Gómez 2010). La extensión del hábitat que se documenta en este sitio se produjo también en Ledesma. En la Primera Edad del Hierro existía una pequeña aldea en la parte septentrional del cerro (Benet et al. 1991; Martín Valls 1999: 140-141, 216). Sin embargo, algunos vestigios cerámicos, el trazado de la muralla medieval, que probablemente sigue el desarrollo de la antigua fortificación prerromana, y el esquema en embudo que conservan algunas de sus puertas, dan pie a sospechar que es ahora cuando la ciudad ocupa su auténtico solar histórico, con una superficie de casi 11 hectáreas.

Una situación muy diferente es la que proporcionan las comunidades asentadas al oeste de Salamanca, en el espacio comprendido entre los ríos Tormes, Duero y Águeda (Figs. 8 y 9). Los conjuntos materiales de estos asentamientos eran similares a los de los oppida abulenses, pero los sitios son significativamente más pequeños, por debajo de las 10 hectáreas. Irueña ronda las 9, Las Merchanas o Yecla la Vieja se acercan a las 5 y el Picón de la Mora abarca algo más de una. Las murallas y otras defensas (fosos, torres, campos de piedras hincadas) son el elemento más llamativo y eso les ha otorgado una entidad propia, faltando de manera general asentamientos de inferior categoría, como granjas y pequeñas aldeas. El 


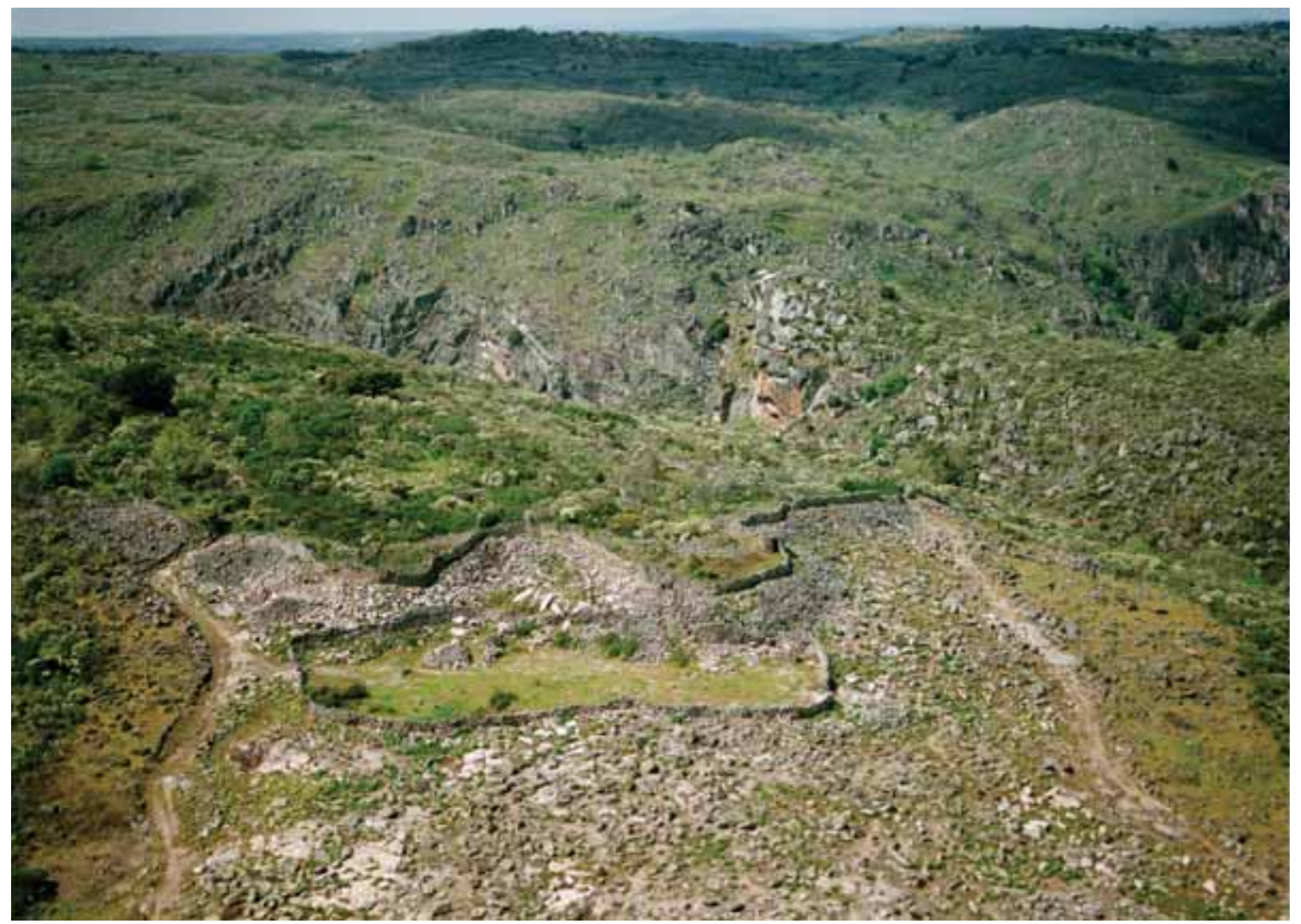

Figura 8.- Vista aérea del castro de Saldeana (Salamanca). Al fondo, el valle del río Huebra (Foto de Jesús Gascón).

grupo más espectacular se localiza junto a los ríos Yeltes y Huebra: en un radio inferior a los $10 \mathrm{Km}$ se cuentan hasta seis poblados de este tipo -Saldeana, El Castillo de Saldañuela, El Picón de la Mora, Los Castillos de Gema, Yecla la Vieja, Las Merchanas- (Álvarez-Sanchís 1999: 120-126; Martín Valls 1999; Benet y López Jiménez 2008). Algunas excavaciones han demostrado la existencia de viviendas extramuros, aunque no se ha podido establecer con claridad su sistema organizativo. Hasta hace no demasiado tiempo, las insculturas graníticas cercanas a la muralla del castro de Yecla constituían un caso excepcional (Fig. 10), pero investigaciones recientes han proporcionado nuevos hallazgos en otros poblados del valle del Huebra (Las Merchanas, Saldeana, Montalvo) que vienen a resaltar la singularidad del grupo yeclense (Martín Valls y Romero 2008). Los territorios de explotación ponen inmediatamente de relieve cómo los poblados están orientados hacia el aprovechamiento de recursos ganaderos. Sin embargo estas aglomeraciones urbanas, sin centros menores suministradores, deben llevar aparejado un modelo mucho más específico de explotación del territorio. Existen importantes afloramientos de mineral en Barruecopardo, Encinasola de los Comendadores, Villares de Yeltes y otros focos más al sur. No hay evidencias arqueológicas seguras de su explotación en época prerromana (López Jiménez 2005; Hernández Sánchez 2011: 144145), pero la hipótesis de vincular el desarrollo

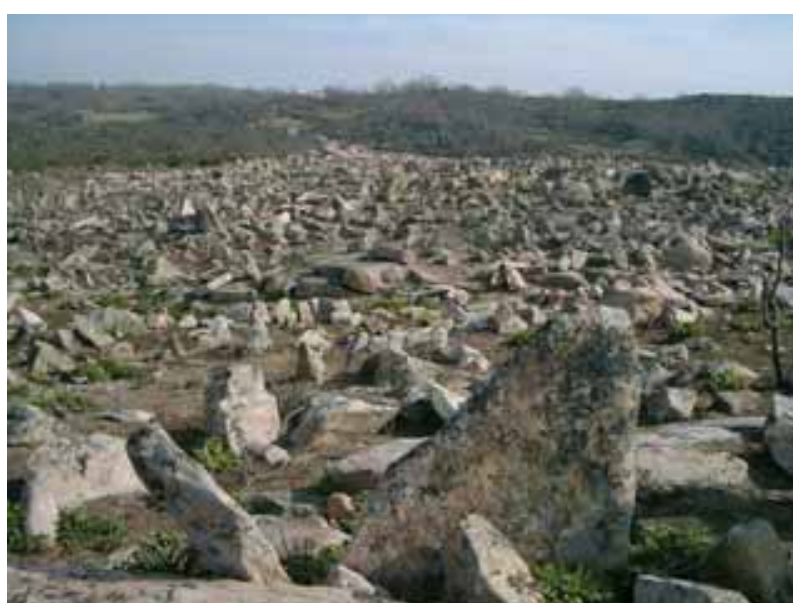

Figura 9.- Campo de piedras hincadas del castro de Saldeana, desde la muralla. 


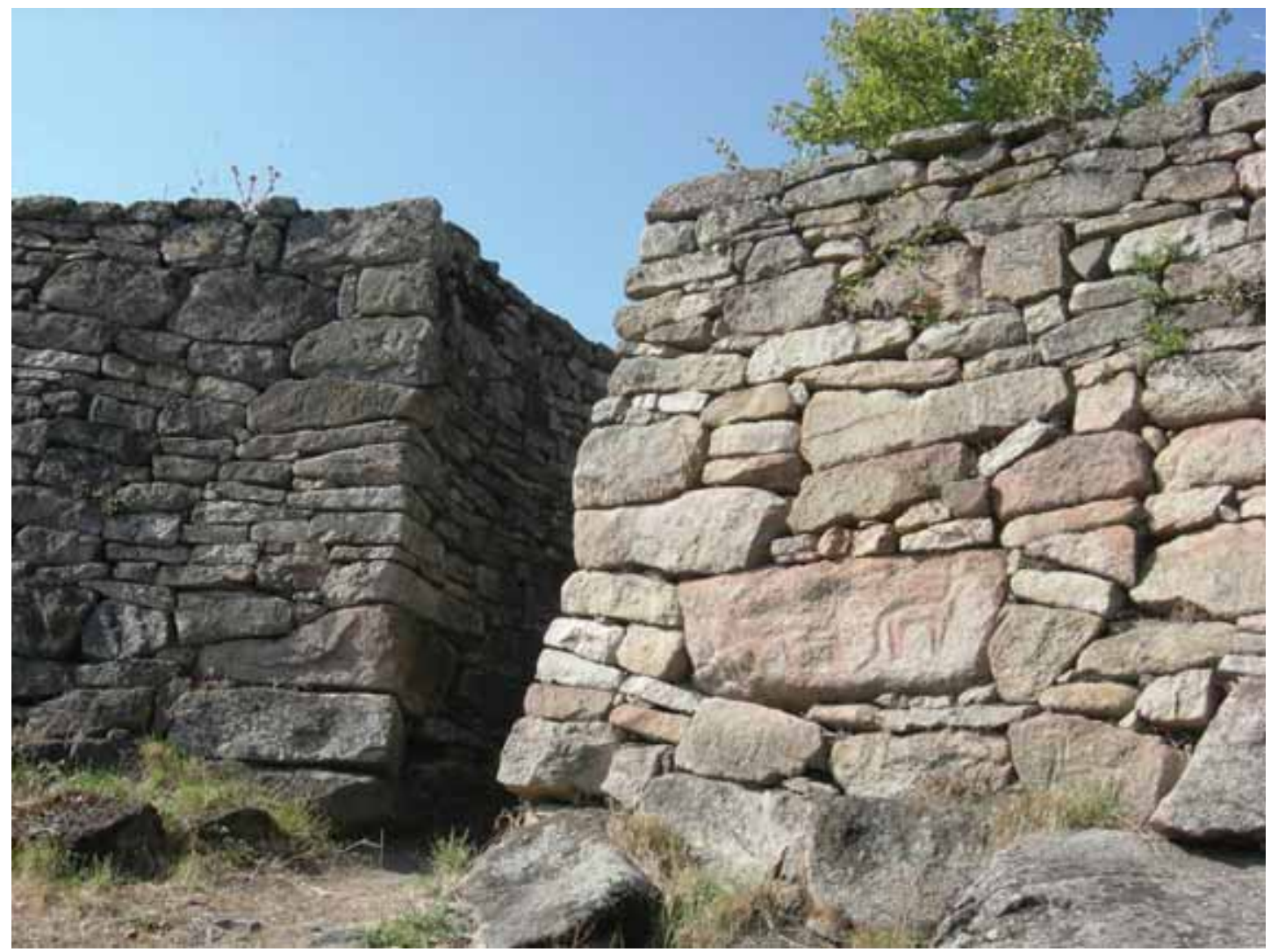

Figura 10.- Grabados de caballos en los sillares de la muralla del castro de Yecla la Vieja (Yecla de Yeltes, Salamanca).

de estos núcleos a dicha actividad nos parece sugestiva (Salinas 1992-93: 179-180; Martín Valls 1999: 166). Su ubicación, en la divisoria entre el Duero y el viejo camino tartésico de la Vía de la Plata (Gillani y Santonja 2007), contribuiría a explicar la pujanza de estos núcleos en las redes de intercambio.

Esta diversidad de formas de poblamiento en la Meseta occidental parece expresar, sin duda, diversidad de organizaciones sociales y económicas. La consideración de los territorios de explotación de los oppida, las pequeñas explotaciones rurales, los sitios especializados y sus presuntas actividades y funciones indican claramente que las diferencias entre las poblaciones de unos y otros debieron existir sin duda alguna.

\subsection{Cementerios y asentamientos: ¿cuántos vettones?}

Un aspecto revelador de la organización interna de estos centros es el de la estimación de los tamaños de población. Para estimar figuras de poblaciones prehistóricas a partir del registro arqueológico se han empleado diversos métodos, ampliamente presentados y discutidos en la disciplina (Hassan 1981; Neustupny 1983; Chamberlain 2006; Bouquet-Appel 2008). La demografía de las sociedades prehistóricas es también un aspecto clave para entender la emergencia de identidades étnicas, cómo y por qué aparecen grupos que se autorreconocen y se diferencian de otros (Ruiz Zapatero 2009: 23 y 2010: 45 ss.). Pero lo habitual es que sólo podamos contar con escasos datos, además de parciales y sesgados.

La demografía de los cementerios vettones y su relación con los asentamientos ha sido abordada en varios trabajos (Ruiz Zapatero y Álvarez-Sanchís 1995; Álvarez-Sanchís 1999: 306308; Álvarez-Sanchís y Ruiz Zapatero 2001), asumiendo que las excavaciones de algunos cementerios fueron bastante exhaustivas y que, razonablemente por tanto, contamos con una cifra de tumbas muy aproximada a los enterramientos reales de la época. El punto de partida viene definido por las dos grandes necrópolis excavadas en la provincia de Ávila en los años 30 del siglo XX, cuyos enterramientos se fechan 


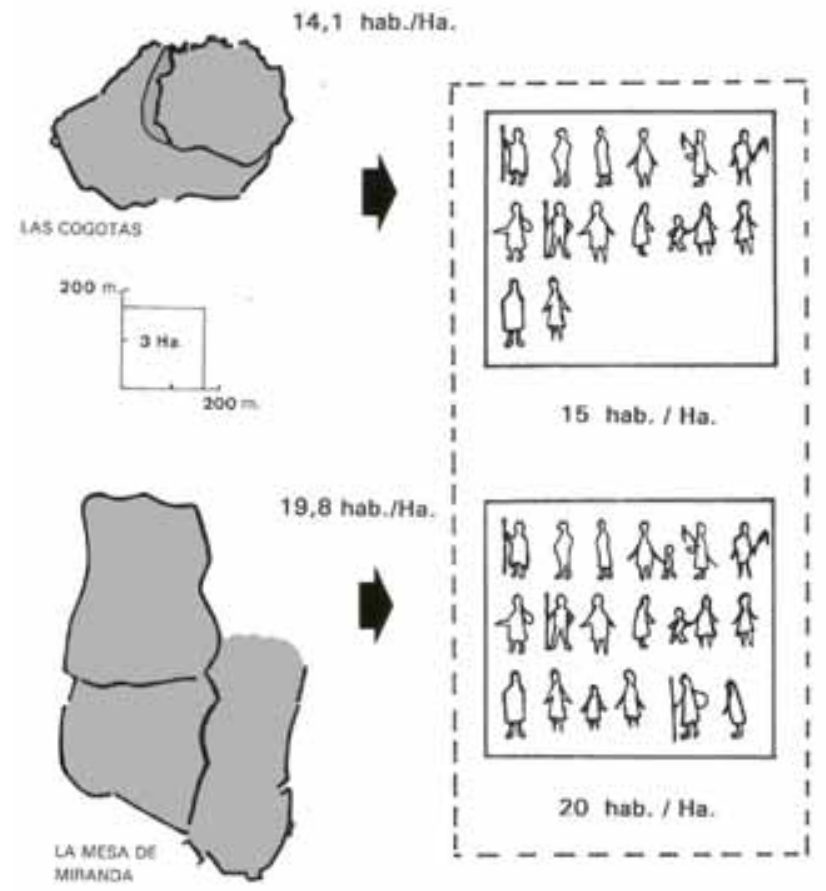

Figura 11.- Densidad de habitantes/ha en los oppida vettones de Las Cogotas y La Mesa de Miranda (Alvarez-Sanchís y Ruiz Zapatero 2001).

aproximadamente entre el siglo IV e inicios del II a.C.: Las Cogotas, con 1613 tumbas repartidas en cuatro zonas, siendo hasta ahora la única publicada prácticamente en su integridad (Cabré 1932), y La Osera, con unas 2230 sepulturas distribuidas en seis zonas (Cabré et al. 1950). Los cálculos estimativos de ambas poblaciones se obtuvieron aplicando la fórmula de Acsádi y Neméskeri (1970; ver también Wells 1984), considerando el total de tumbas excavadas, asumiendo un valor de 30 años como esperanza de vida media de la época, distintos valores a los años de duración de ambos cementerios y estimando un factor de corrección del $10-20 \%$ para compensar los enterramientos destruidos. Con estos datos, es razonable pensar que en Las Cogotas habitó una comunidad que debió oscilar entre los 200 y 300 habitantes, al tiempo que en La Mesa de Miranda la necrópolis reflejaría una población en torno a los 300400 habitantes.

La densidad de población por unidad de superficie es otro dato interesante. Con las estimaciones demográficas de Las Cogotas y La Mesa de Miranda, estaríamos hablando de alrededor de $15 \mathrm{hab} / \mathrm{ha}$ en el primer caso, y cerca de 20 hab/ha en el segundo (Fig. 11). El hecho de que sobre la base de los enterramientos tengamos los tamaños de población de cada comunidad y que resulten comparables los valores de densidad de población por hectárea ocupada, sugiere la existencia de una posible relación constante entre el espacio intramuros y el censo total de población. En otros casos, como en Ulaca, contamos sólo con la superficie ( $c a .70$ ha) y una aproximación sobre las estructuras de habitación. Aplicando los valores de densidad de habitantes por hectárea anteriores resultarían unas figuras de entre 1.050 y 1.400 habitantes. Estas cifras se ajustan bastante bien a las 250 estructuras documentadas en la superficie del poblado tras una intensa prospección (Álvarez-Sanchís 1999: 139 ss., nota 110$)$. Sabemos además que el hábitat se extendió fuera del recinto fortificado, en dirección noreste. Todo ello no impide admitir un mayor volumen de población eventual por razones defensivas en un momento de inestabilidad social o conflicto bélico, hasta casi doblar la población residente (2.000-2.500 hab.), especialmente si tenemos en cuenta los amplios espacios interiores del poblado sin evidencias de ocupación. El castro de El Raso, al otro lado del Sistema Central, se extiende sobre una superficie de unas 20 ha y podría interpretarse de manera análoga que su población estuviera entre los 400 y 500 habitantes. Aunque también hay que reconocer que al tratarse de un poblado ocupado en las postrimerías de la conquista romana podría encubrir una población mayor. En cualquier caso la estimación de su excavador, Fernández Gómez (1986: $949-50$ y 2008: 195-196), en torno a unos tres millares de personas, teniendo en cuenta las viviendas excavadas y considerando que la mitad del poblado estuviese dedicado a construcciones privadas, resulta excesiva en mi opinión.

Conocemos muy mal la trama de poblamiento comarcal, con núcleos menores. Y, desde luego, desconocemos si pequeñas granjas y explotaciones rurales próximas a los oppida enterraron a sus difuntos en los cementerios de aquéllos o bien formaron pequeños panteones familiares que resultarían, por lo reducido del número de tumbas, bastante difíciles de descubrir (Fig. 12). En algunos casos tenemos indicios de estas alquerías y pequeños establecimientos pero no de sus tumbas, y en muchos casos tal vez haya que pensar que unas y otras, granjas y explotaciones 
rurales y agrupaciones de tumbas familiares, son invisibles por la falta de prospecciones intensivas. Idealmente estaríamos hablando de alquerías con 5 ó 6 casas y pequeñas aldeas con un máximo de 10-15 hogares. A tenor de los castros conocidos y su tamaño, comarcas como el valle Amblés estarían densamente ocupadas, lo que en absoluto refleja el valor medio del poblamiento de la época a escala suprarregional. Al lado existirían áreas muy débilmente pobladas cuando no prácticamente deshabitadas. Se ha estimado que los castros salmantinos concentrados en torno a los ríos Yeltes-Huebra y su territorio inmediato, arrojaran una población absoluta en torno a los 2.000-4.000 habitantes. Apoyarían esta suposición las dimensiones más pequeñas de los poblados y la escasa superficie útil para el caserío. Pero al conocer muy poco la anatomía residencial de los asentamientos no es posible adjudicar valores uniformes de población por unidad de superficie. La diversidad de las densidades de población en la Edad del Hierro deberá ser muy tenida en cuenta en futuros estudios demográficos. En todo caso, los tamaños de las comunidades vettonas a partir de los cementerios y las superficies de los asentamientos asociados, con diferencias que pudieron ser significativas, nos están indicando que por detrás de la demo-

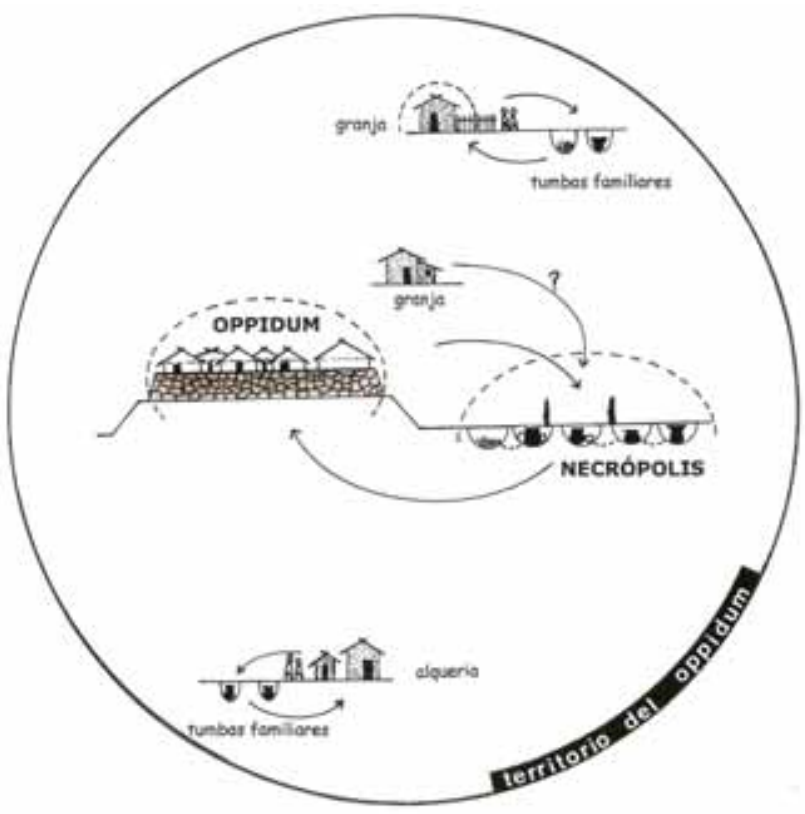

Figura 12.- Posibles unidades de asentamiento y funerarias en el territorio controlado por un oppidum, y diferentes visibilidades en el registro arqueológico (Álvarez-Sanchís y Ruiz Zapatero 2001). grafía existen otros aspectos importantes implicados, como la organización social, la economía básica de subsistencia o las tradiciones culturales de sus gentes.

\subsection{Espacios sociales y espacios simbólicos}

El armamento conservado en las necrópolis ofrece combinaciones que parecen reflejar identidades sociales entre los grupos guerreros, desde sepulturas muy ricas pero minoritarias con panoplias completas que incluyen espada, escudo, una pareja de lanzas y arreos de caba1lo, hasta otras que sólo llevan armas de asta, por tanto el equipo básico del infante ligero (Figs. 13 y 14). Teniendo en cuenta las tumbas de estos equites y las tumbas con armas sin elementos de atalaje, la proporción teórica jinete/ infante sería aproximadamente de 1/4 en Las Cogotas y $1 / 6$ en La Osera, similar a la proporción que se daba en otras poblaciones célticas y entre los propios celtíberos. Las comunidades vettonas eran comunidades desiguales, lideradas por una aristocracia poseedora de caballos y armas suntuarias que marcaba su posición frente a grupos de guerreros con panoplias más sencillas (Martín Valls 1986-87: 78; ÁlvarezSanchís 1999: 295 ss.). Cierta gradación también parece factible en las tumbas que podríamos considerar teóricamente femeninas, unas pocas con ricos elementos de adorno (brazaletes, collares, fíbulas, broches) y otras con ajuares bastante más pobres. Estudios recientes han reforzado la idea de un sacerdocio institucionalizado entre los vettones. Baquedano y Escorza (1998 y 2009) han analizado en el cementerio de La Osera la distribución de las estelas de piedra que señalan los distintos grupos enterrados y todo apunta a que pudieron funcionar como marcadores de los días más importantes del año (solsticios de verano e invierno y fiestas célticas) e incluso su distribución reflejaría el mapa celeste de la época. Otro tanto puede decirse del altar de Ulaca y su orientación topo-astronómica (Pérez Gutiérrez 2010: 180 ss.). Cuando el sol se sitúa sobre la cumbre de la Sierra de la Paramera, conocida como "Risco del Sol", la pendiente de las dos escaleras del altar apunta a la posición que tiene el astro en las fechas del solsticio de invierno. 


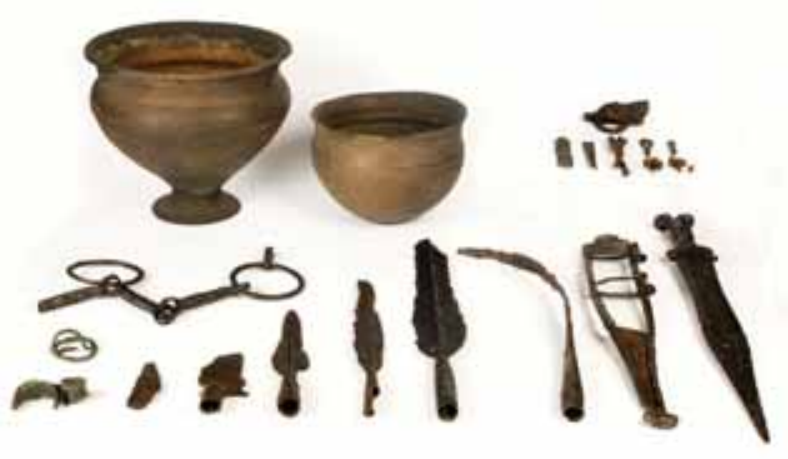

Figura 13.- Ajuar de la sepultura de guerrero $\mathrm{n}^{\mathrm{o}} 270$, zona VI de la necrópolis de La Osera (foto de Mario Torquemada, Museo Arqueológico Regional, Madrid).

Son muy pocos los enterramientos que se puedan relacionar con hombres y mujeres dedicados al trabajo industrial (metalurgia, alfarería, curtido de pieles, trabajo de la piedra y la madera...), pero sin duda existieron especialistas como evidencian las herramientas halladas en los contextos domésticos de los oppida. Muchos agricultores pueden haber sido artesanos a tiempo parcial, e incluso unos pocos en los meses de invierno podían embarcarse en pequeñas aventuras comerciales. A pesar de todo, una estimación razonable es que cuatro de cada cinco tumbas sólo contenían cenizas o la urna cineraria (Álvarez-Sanchís 2003b: 86-
92); éstas corresponderían a los individuos más humildes y tal vez a siervos o esclavos, aunque su detección resulta muy difícil de probar (Balter 1995). La actividad de estas personas iría enfocada a las labores básicas del proceso productivo: el trabajo agrícola, el cuidado de los ganados y la construcción y reparación de las defensas del poblado. Sin embargo, todavía carecemos de buenos datos para representar con precisión las comunidades vettonas. Los cementerios dejan entrever una fuerte jerarquización a partir de las disimetrías de los ajuares funerarios (Fig. 15), pero nuestra información queda reducida a lo que sabemos de sus élites (Ruiz Zapatero 2007); el resto de la población es prácticamente invisible en el registro arqueológico y en las fuentes grecorromanas (Fig. 16). Al mismo tiempo, tenemos muy poca documentación sobre los contextos domésticos en los poblados y las formas de producir y acumular riqueza a nivel familiar. Cuestiones relevantes como el estudio de las identidades de clase (Hill 2006), género (Arnold y Vicker 2001) y edad (Díaz Andreu et al. 2005), a pesar de los muchos problemas que presentan, pueden proporcionar nuevas dimensiones para saber cómo funcionaron las sociedades de la Edad del Hierro, entre ellas las vettonas.

Un hecho relevante en la organización espacial de estos cementerios es la posibilidad de re-
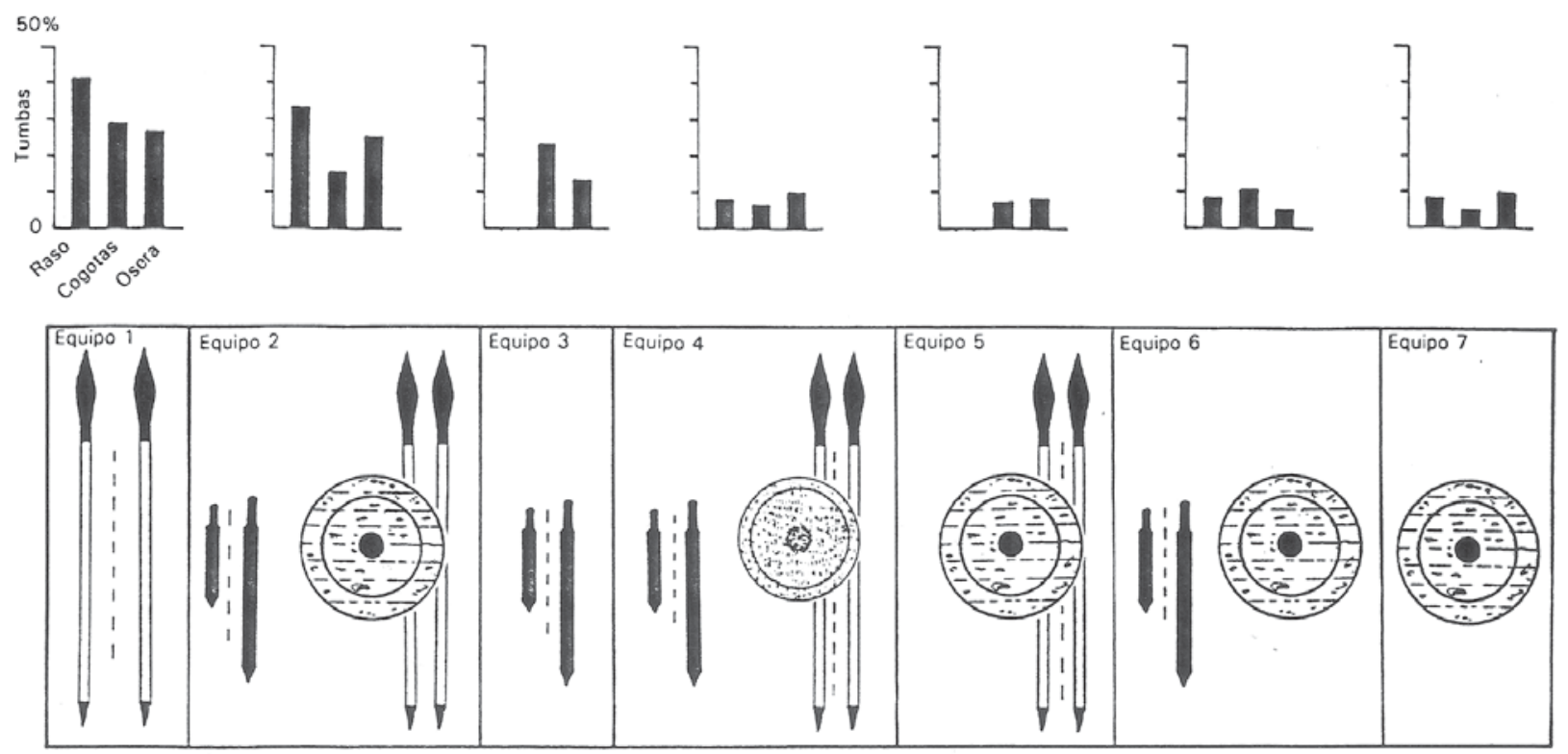

Figura 14.- Equipos militares de las necrópolis vettonas a partir de los datos de El Raso, Las Cogotas y La Osera (zona VI). Los diagramas de barras ofrecen los porcentajes respecto al total de tumbas con armamento (Álvarez-Sanchís 1999). 

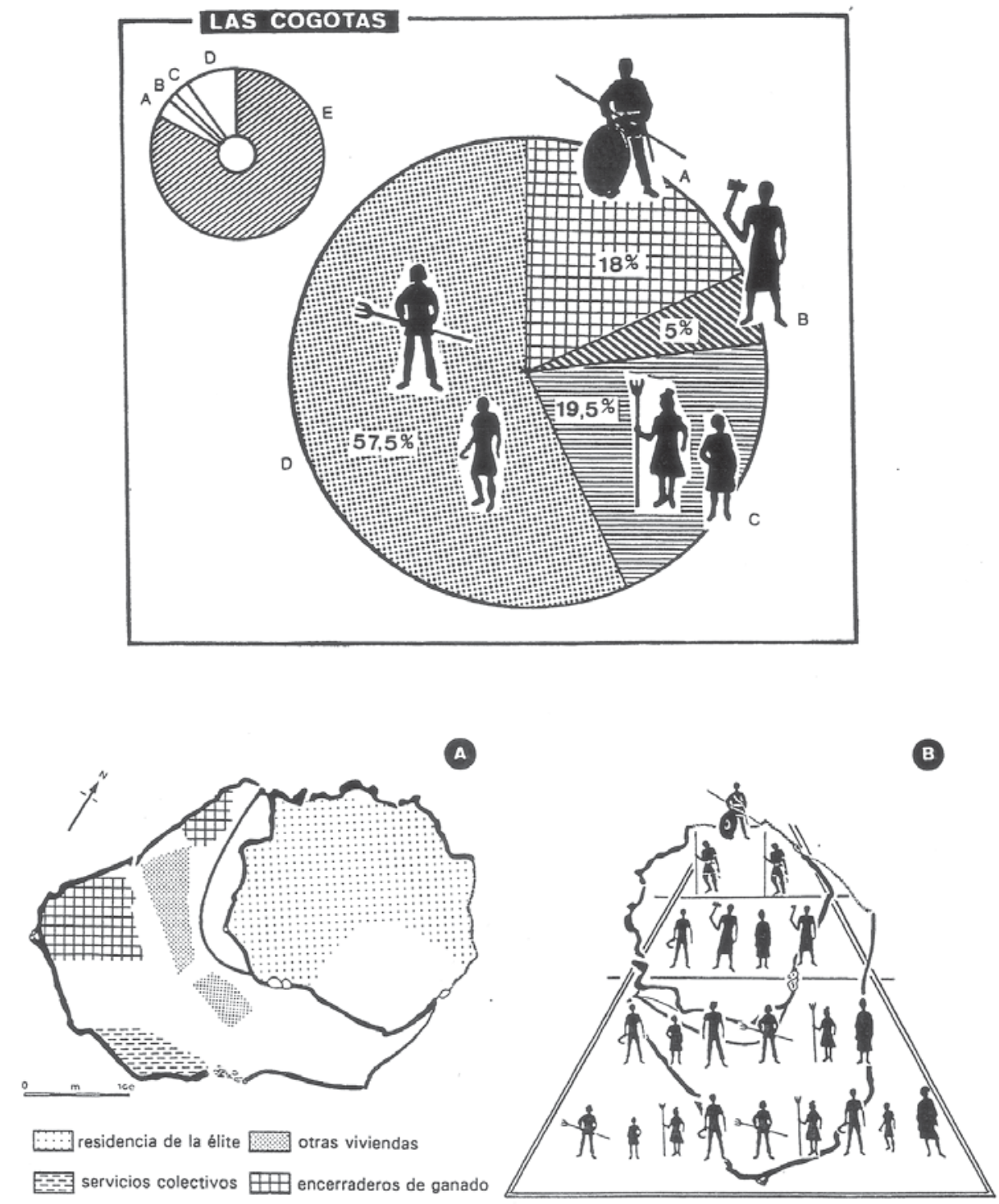

Figura 15.- Áreas funcionales de Las Cogotas, estructura piramidal de la comunidad a partir de los enterramientos y distribución de los ajuares funerarios según categorías sociales: A, guerreros; B, especialistas; C, mujeres; D, otros y E, tumbas sin ajuar (Ruiz Zapatero y Álvarez-Sanchís 1995, modificado)

conocer grupos familiares diferenciados (Castro 1986: 129 ss.; Kurtz 1987: 257 ss.; Martín Valls 1986-87: 75-78). Los enterramientos de Las Cogotas, La Osera y El Raso se distribuyen en zonas claramente separadas entre sí por espacios estériles. La evidencia de tumbas socialmente preeminentes en cada área y la gran diversificación de ajuares permiten inferir contradicciones internas en la estructura social y familiar (Fig. 17). Se ha debatido mucho su significado. La contemporaneidad de las diferentes zonas está fuera de toda duda (Álvarez-Sanchís 2003b: 81 ss.) y es razonable suponer que las áreas funerarias están reflejando un sistema de descendencia lineal en los grupos familiares, cuya economía se basaba en el control de los medios de producción, que no podemos precisar, y que se enterraban separadamente para reforzar simbólicamente sus derechos y obligaciones. Este nuevo paisaje funerario hay que vincularlo a los cambios que se están sucediendo en las prácticas agropecuarias y en la transmisión de la herencia. Dicho de otro modo, nos informan sobre la estructura social del grupo, del asentamiento y del territorio.

Podemos ir más allá y relacionar el desarrollo de los oppida con parcelaciones importantes en el paisaje que incluyen esas relaciones 


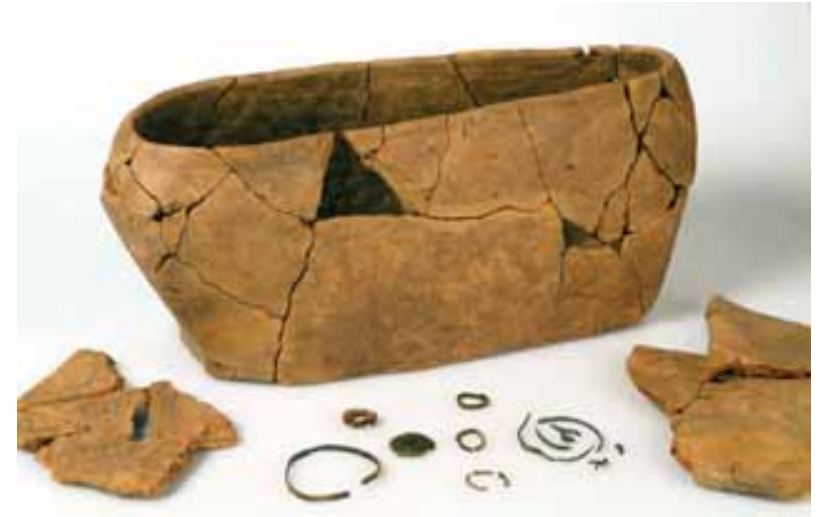

Figura 16.- Ajuar de la sepultura infantil $n^{\circ} 79$ de la necrópolis de El Raso, sector Las Guijas (foto de Mario Torquemada, Museo Arqueológico Regional, Madrid).

de poder. Los verracos y las cerámicas a peine son, en este sentido, indicadores simbólicos muy útiles para explorar su utilización en la Edad del Hierro (Ruiz Zapatero y Álvarez-Sanchís 2002). Me referiré en primer lugar a la ubicación de los famosos verracos, singulares efigies de granito que representan toros y cerdos. El área de dispersión de estas esculturas abarca las tierras occidentales de la Meseta, Extremadura y la región portuguesa de Tras-os-Montes, es decir, coinciden en una gran parte con el territorio que las fuentes antiguas adjudican a los vettones históricos (Fig. 18). El estado de la documentación arqueológica relativa a estas esculturas no ha variado mucho en las décadas transcurridas desde los trabajos de Cabré (Álvarez-Sanchís 2008). El inventario de piezas ha crecido de forma muy considerable y hoy se conocen más de 400 piezas, pero la información cualificada procedente de excavaciones ha sido mucho más modesta.

Desde hace tiempo, vengo reconsiderando el papel tradicional -divinidades protectoras de los ganados, monumentos funerarios de época romana- asignado a estas esculturas (ÁlvarezSanchís 1999: 262 ss.). Sabemos que una parte muy importante de los verracos -muchos de dimensiones superiores a los $2 \mathrm{~m}$ de longitud y entre 3 y 8 toneladas de peso -fueron esculpidos entre mediados del siglo IV a.C. y el siglo I a.C. La localización de estas figuras en el paisaje es un factor importante a la hora de abordar su significado y análisis locacionales y de visibilidad en algunas comarcas como el

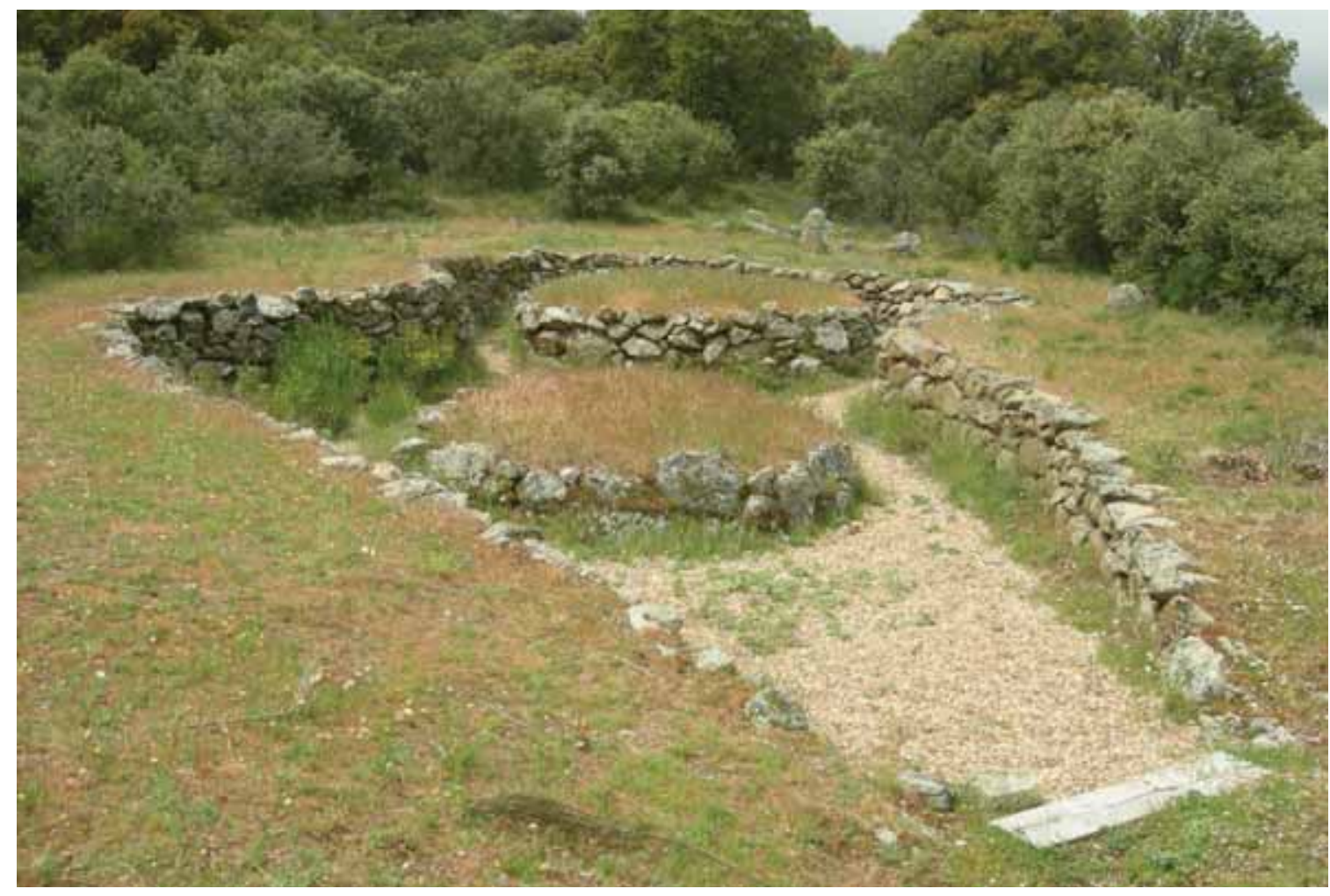

Figura 17.- Túmulos de un sector de la necrópolis de La Osera, delimitados por una estructura de mampostería. 


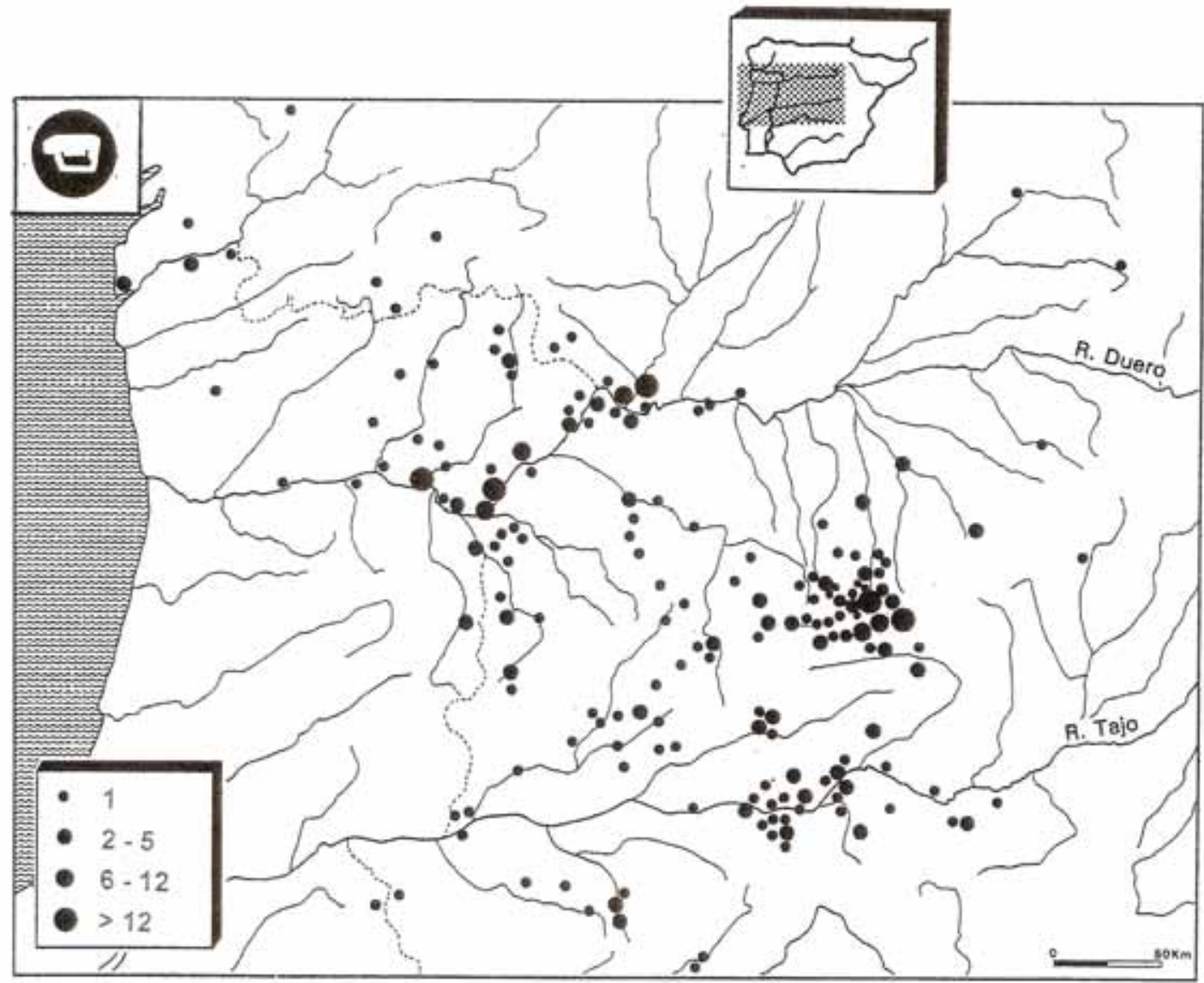

Figura 18.- Distribución geográfica de la escultura zoomorfa (toros y verracos) según el número de ejemplares (Álvarez-Sanchís 2003).

valle Amblés, el oeste de Salamanca y el valle medio del Tajo, van en esa dirección (ÁlvarezSanchís 2003b: 55-63 y 2007a; Charro Lobato 2009). La creación de monumentos como los Toros de Guisando (El Tiemblo), Berrocal de Padierno (Tabera de Abajo) o el toro de Villanueva del Campillo (Fig. 19) debió ser un episodio importante en la organización del paisaje durante la Segunda Edad del Hierro, y esto podría explicar el desarrollo de nuevos límites en los campos prehistóricos, resultado de un proceso de afianzamiento de las élites en la posesión de cabezas de ganado, pastos y tierras de cultivo (Álvarez-Sanchís y Ruiz Zapatero 1999). Sabemos que los mejores pastos de los valles y las fuentes de agua más próximas fueron referenciados en el paisaje de la época mediante la erección de estas esculturas y que los vettones erigieron estos monumentos para legitimar sus derechos sobre los pastos y el ganado, en comarcas que pudieron alcanzar una relativa alta densidad de poblamiento (Fig. 20). Análisis palinológicos recientes llevados a cabo en los castros de Ávila revelan en su conjunto un proceso de explotación del paisaje extremadamente extenso, y por tanto la transformación de los antiguos bosques en amplios territorios de pastos y tierras de cultivo (López Sáez et al. 2008 y 2009). Pero seguimos sin conocer en extensión cómo eran los paisajes de la Edad del Hierro (Blanco y Fabián 2005; Blanco 2008), al tiempo que precisamos indagar a escala micro la ubicación de los verracos (Ruiz Zapatero y Álvarez-Sanchís 2008).

Esta lectura no ha dejado de suscitar polémica y agudas críticas (Martín Valls y Pérez Gómez 2004). Con todo, dicha hipótesis no invalida que en otros casos los verracos fueran elementos protectores de la comunidad, pues sabemos que algunos fueron erigidos en el interior de los castros (La Mesa de Miranda, Irueña) o junto a las entradas y caminos de acceso (Las Cogotas, Las Merchanas, Yecla). Este dato permite plantear una función apotropaica, como defensoras del poblado y el ganado, lo que no desentona en absoluto con la 


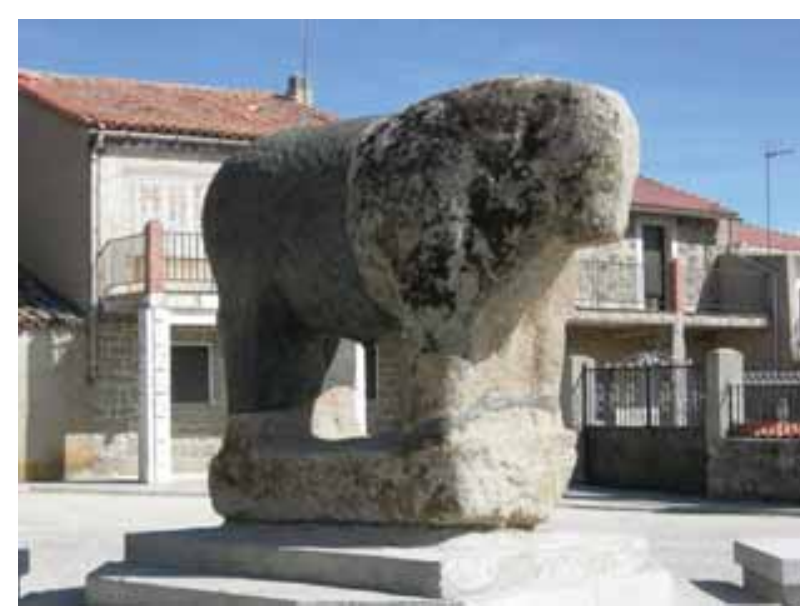

Figura 19.- Escultura de toro de Villanueva del Campillo (Ávila). Se conserva en la plaza del pueblo de la citada localidad.

vieja idea de Cabré (1930: 39-40). Es más, su acertada reflexión respecto al emplazamiento del jabalí y los dos toros de Las Cogotas, se ha visto corroborada con el hallazgo de otros dos ejemplares junto a la zona de piedras hincadas. Este mismo aspecto ha sido valorado y enriquecido por Esparza (2003: 173-174), al dotar a las piedras hincadas de un contenido simbólico de protección y prestigio, basado precisamente en la idea de que estas esculturas tuvie- ron una función apotropaica. Por otra parte, el descubrimiento en la base de la torre norte de la puerta de San Vicente, en las murallas de Ávila, de un verraco de $1,70 \mathrm{~m}$ de longitud tallado in situ en la misma piedra, sobre el substrato geológico de la ciudad, constituye uno de los hallazgos más espectaculares y recientes $(\mathrm{Gu}-$ tiérrez Robledo 1999; Martínez Lillo y Murillo 2003). La escultura servía de cimiento de una primitiva torre romana que tenía su entrada por el mismo lugar que ahora tiene la puerta medieval. Es casi seguro que estuviese a la vista en época romana, pero tampoco hay que descartar que flanqueara el acceso a lo que debió ser el primitivo castro prerromano, tal vez con la simbología característica del guardián protector de la ciudad (Álvarez-Sanchís 2003b: 58). Excavaciones recientes en el mismo sitio han deparado el hallazgo de un segundo verraco (Cantalapiedra 2007), que no hace sino confirmar lo dicho.

Algunos verracos se han interpretado como sencillos monumentos funerarios entre los vettones romanizados. Así se constata en las esculturas halladas en la localidad abulense de Martiherrero (Martín Valls y Pérez Herrero 1976) o, en términos generales, en aquellas que portan inscripciones latinas. Pero la

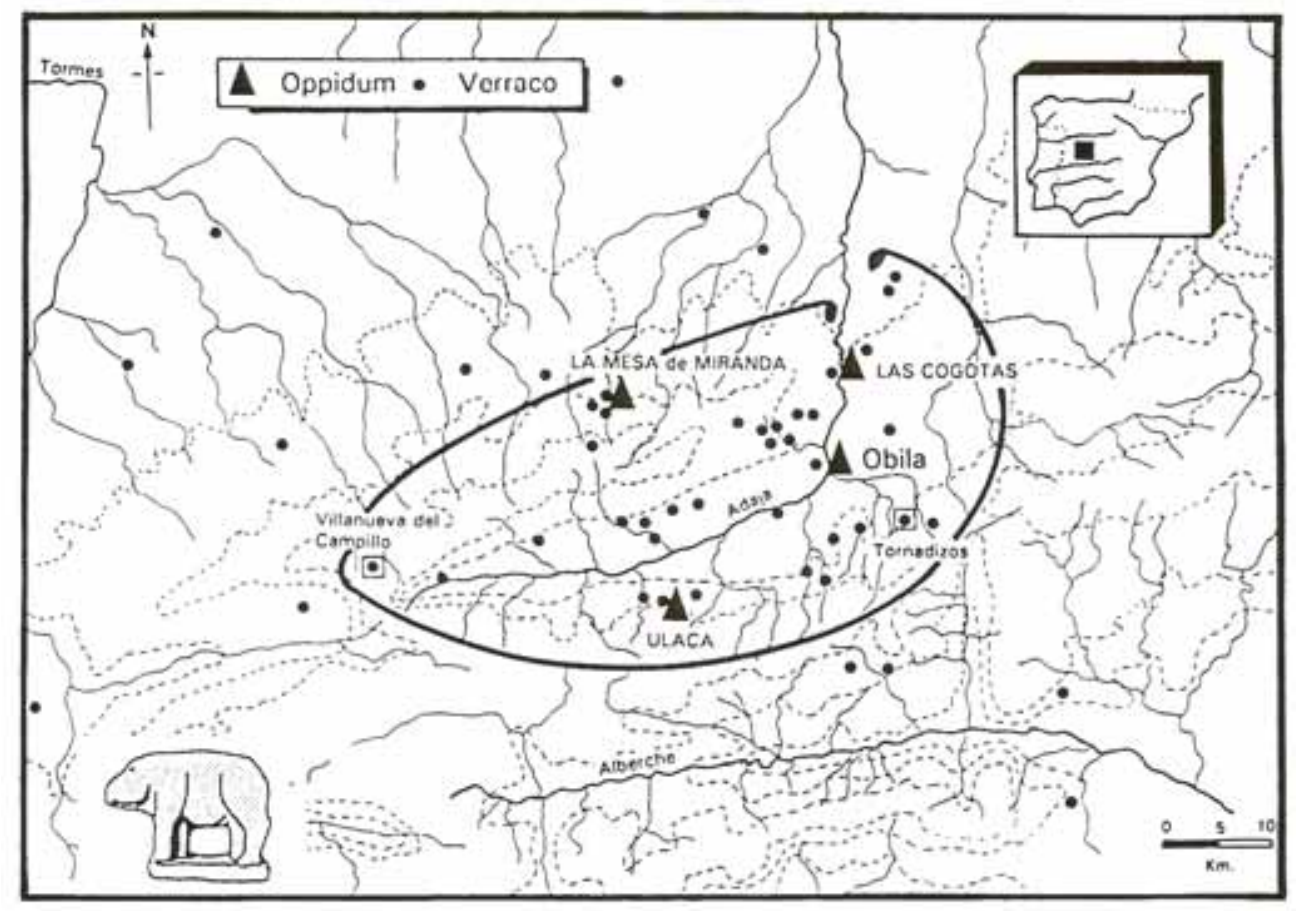

Figura 20.- Mapa de los oppida del valle Amblés y distribución de los verracos y áreas limítrofes (Álvarez-Sanchís 1999). 
consideración de estas esculturas como tumbas sólo afecta a una parte minoritaria de los verracos conocidos y no se puede descartar que fueran realizados en época prerromana. Una parte de estas representaciones pudieron, por tanto, gozar de cierto protagonismo en el imaginario colectivo de los vettones romanizados. Ese significado es independiente del papel que las estatuas desempeñaron en la organización del territorio durante la Segunda Edad del Hierro, pero no alterarían lo esencial de su función, a saber, la transmisión de la ideología de un grupo de poder.

Otra contribución positiva a la etnicidad pretérita de los pueblos prerromanos es el estudio de sus cerámicas. La decoración de los recipientes transmiten información de los hombres y mujeres que los usan, de la misma manera que los trajes populares en las comunidades campesinas nos informan sobre la edad, el estado civil y el territorio de origen de sus portadores, algo evidente en Europa por lo menos desde la Edad del Bronce (Wels-Weyrauch 1994; Fernández Götz 2008: 129). La dimensión específica de la etnicidad en la cerámica se ha discutido desde estudios etnoarqueológicos y antropológicos (Bowser 2000; González Ruibal 2003: 117-123). Se han desarrollado métodos para estudiar la variabilidad estilística de las decoraciones (Hole 1984; Härdth 198586) y se han realizado brillantes aplicaciones a contextos de la Edad del Hierro europea (Rowlett 1989; Wells 1998).

Un ejemplo práctico de estas ideas fue nuestro ensayo sobre la etnicidad vettona y el recurso de las cerámicas a peine para rastrear arqueológicamente la configuración de este pueblo prerromano (Ruiz Zapatero y ÁlvarezSanchís 2002). En esta tarea partimos de dos premisas: un grupo étnico conocido en las fuentes y un territorio históricamente documentado, cuestiones ambas cruciales para hacer viable una arqueología de la etnicidad (Ruiz Zapatero 2009: 18-19; Álvarez-Sanchís 2010). El análisis detallado de las cerámicas nos llevó a plantear la existencia de tres tipos de categorías: motivos comunes de la tradición cerámica, motivos predominantes en comarcas o regiones, y motivos exclusivos de algunos asentamientos. Muestras significativas como las de Padilla de Duero, con más de 200 vasos recuperados, Las

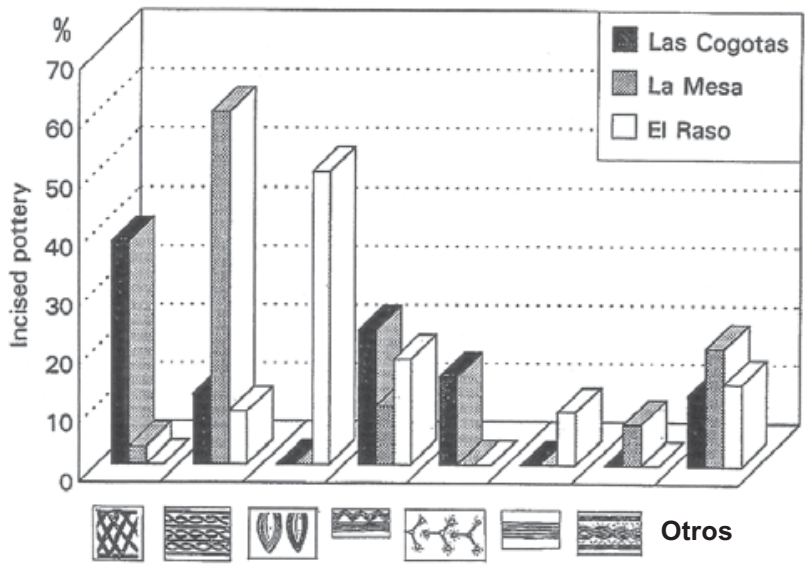

Figura 21.- Motivos de las cerámicas con decoración a peine y diferencias estilísticas a nivel de asentamiento (Álvarez-Sanchís 1999, modificado).

Cogotas, con 97 ejemplares, o la zona VI de La Osera, con 57, han permitido valorar que sobre la base de un peine sencillo compartido en la Primera Edad del Hierro, los alfareros vacceos y vettones desarrollaron talleres muy personales. La coincidencia entre las producciones incisas del ámbito vettón (Las Cogotas, La Mesa, El Raso, Salamanca, Villanueva de la Vera) y un gusto mucho más acusado por las cerámicas impresas o inciso-impresas en las comunidades vacceas (Coca, Cuéllar, La Mota, Padilla, Olivares de Duero, Roa) y arévacas (Tiermes, Luzaga), tiene suficiente entidad para acreditar lo dicho. Otro indicio en este mismo sentido sería la predilección por los temas en espiguilla y líneas de puntillado en las necrópolis del Alto y Medio Duero, frente a las barrocas cesterías de la Meseta occidental.

De igual manera, un análisis de las decoraciones permite descender no sólo a la atribución étnica de la alfarería, sino incluso al carácter microlocacional de la misma (Álvarez-Sanchís 1999: 304). Sólo en las necrópolis vettonas (Fig. 21), los cuatro motivos más abundantes proporcionaron distintas frecuencias: temas de cestería (38\%), bandas en zigzag $(23 \%)$, soles/ estrellas $(15 \%)$ y sogueados $(12 \%)$ en el caso de Las Cogotas; sogueados $(60 \%)$, bandas en zigzag $(10 \%)$, sogueado/zigzag $(7 \%)$ y cestería (3\%) en La Osera; y motivos almendrados $(50 \%)$, bandas en zigzag (18\%), sogueados $(9 \%)$ y bandas horizontales o verticales $(9 \%)$ en El Raso. Esta flexibilidad también pudo apreciar- 
se considerando el número de púas usado en los peines, aunque plantea problemas insolubles si se tiene en cuenta el grado de conservación de las piezas. De todas maneras, en una primera apreciación, los peines de 2 y 3 púas acaparan más de la mitad de la muestra en Las Cogotas. En el Raso se podrían situar entre 3 y 4, mientras La Osera reclama sobre todo modelos de 4 y 5 púas. La impresión que se obtiene es que existen marcadas diferencias a nivel de asentamiento. En otras palabras, las identidades estilísticas cerámicas deben ser la expresión de identidades sociales, de comunidades que se diferencian y reconocen como distintas, pero compartiendo la misma tradición cerámica y decorativa. Si los verracos materializan la etnicidad en el territorio, las cerámicas a peine la construyen en las relaciones sociales cotidianas de los oppida a través de la visualización de las composiciones decorativas y los mensajes icónicos que éstas encierran.

En resumen, de la lectura de estos últimos datos pueden extraerse algunas consideraciones relativas al problema que plantea la relación etnia-ciudad, y que debemos situar desde un punto de vista arqueológico con anterioridad a la llegada de Roma:

(1) la existencia de una población de la Edad del Hierro en el oeste de la Meseta, que se corresponde con el territorio histórico de los vettones que testimonian las fuentes romanas,

(2) un segundo rango vertebrado en agrupaciones tribales menores que confluyen en valles y comarcas específicas, con un patrón de ocupación social y económico también específico,

(3) una última categoría vinculada a los $o p$ pida como elementos jerarquizadores del territorio, que empiezan a ofrecer rasgos de comunidades que se diferencian y reconocen como distintas, pero compartiendo idéntica cultura material.

Las gentes vettonas que se articularon en torno a los oppida reordenaron el paisaje y controlaron los campos de cultivo y los pastos de sus territorios circundantes. El nivel de desarrollo social y económico alcanzado favorecería situaciones conflictivas entre comunidades próximas. Existe, como hemos visto, una amplia evidencia que testimonia en este momento la importancia del armamento, del guerrero individual y de su estatus en la sociedad (Cunliffe 2003: 94-96). Los equipos militares de los cementerios vettones coinciden en lo básico con el registro conocido en los cementerios vacceos, celtibéricos y de otros pueblos del interior. Hasta cierto punto esto sugiere que las distintas elites de la Meseta estaban en contacto y supone la existencia de una "ideología guerrera" compartida (Lorrio y Ruiz Zapatero 2005; Almagro-Gorbea 2008 y 2009). La proliferación de asentamientos fortificados, un fenómeno que exigió la inversión de importantes recursos naturales y humanos, encaja bastante bien con el panorama descrito. Las reconstrucciones y reelaboraciones de las defensas fueron usuales en la época, evolucionaron hacia formas de mayor complejidad y alcanzaron su máxima expresión en las últimas dos centurias antes del cambio de era (Ruiz Zapatero 2003). Desconocemos qué criterios han llevado a escoger una u otra fórmula defensiva, pero el hecho más sobresaliente es que algunos poblados vettones están empezando a comportarse como importantes centros urbanos, y eso, de algún modo, implica un riesgo en la estructura tribal del territorio. A comienzos del siglo II a.C. el sistema socio-económico había alcanzado tal grado de complejidad, que la transformación parecía inevitable. El conflicto con Roma jugará un papel fundamental en su desarrollo.

\section{Hacia la formación de los oppida (c. 200-50 a.C.): los estímulos externos}

Una parte importante de los arqueólogos e historiadores sigue considerando la conquista de Europa y de la Península Ibérica por parte de los romanos, como un factor aislado e independiente del desarrollo de las sociedades prehistóricas. La tradición disciplinar ha tendido a estudiar de forma netamente diferenciada, por un lado la Europa prehistórica y templada, y por otro la historia y cultura romanas (Wells 2002: 379). Sin embargo, el estudio de las gentes de la Edad del Hierro debería pasar por el desarrollo de una aproximación completamen- 
te integrada, tanto a escala regional como de asentamiento.

Mucho más importante para la economía autóctona fue el intercambio comercial con Roma. A comienzos del siglo II a.C. se reconoce cierta inestabilidad en las tierras centrales del Tajo, una región por la que Roma ya había empezado a mostrar un especial interés. Destaca una fecha importante, el 193 a.C., año de una expedición militar al mando del pretor M. Fulvio contra el oppidum carpetano de Toletum -Toledo- y sus alrededores, venciendo a una confederación de tribus vacceas, celtíberas y vettonas (Roldán Hervás 1968-69: 93-94). Los vettones ocupaban en este momento un territorio amplio en torno al valle del Tajo, extendiéndose al norte casi hasta el Duero, donde limitaban con los vacceos, e incluso con el propio río, que separaba a éstos de los astures (Plinio N-H. 4,112-113). Al sur, las sierras de San Pedro, Montánchez y Guadalupe, seguramente dividían a vettones de lusitanos y celtici. La atribución étnica de Obila y Salmantica a los primeros (Ptolomeo 2,5,7) valdría para los límites oriental y occidental, lindando de esta manera con carpetanos y lusitanos.

El centro político y económico de muchas tribus giraba en torno a los oppida, donde seguramente se realizaban las transacciones comerciales más importantes, y como tales constituían una atracción para los mercaderes extranjeros. Por eso el aumento de la demanda de materias primas y de mano de obra por parte del mundo romano tuvo que suponer un enorme estímulo para la producción local y sus dirigentes, lo que aceleró el desarrollo de estos centros. Hacia ellos arribaron no sólo monedas de plata y bronce a cambio de esclavos, metal, ganado y productos agrícolas como el trigo, sino también vino, aceite, perfumes, telas, servicios de vajilla y otros objetos de lujo mediterráneos, además de incontables chucherías y baratijas. En las relaciones comerciales intervenían múltiples productos. A finales del siglo III a.C. se fechan las primeras importaciones romanas y a lo largo del siglo II a.C. cerámicas campanienses, denarios y otros productos empiezan a proliferar en sitios como Salamanca, Toro, Las Cogotas, La Mesa de Miranda o el Raso (Martín Valls y Esparza 1992: 272; Álvarez-Sanchís 2003b: 129 ss.). La conquista de la Meseta supuso una completa reorganiza- ción de las pautas comerciales tradicionales. La realidad concreta de los mecanismos de intercambio empleados no se acaba de conocer bien del todo, pero a juzgar por los datos que nos han transmitido los escritores clásicos las mercancías se obtenían fundamentalmente a través del comercio organizado, del intercambio diplomático de dones y del pillaje (Cunliffe 1998). Un sistema de intercambio más complejo que el practicado hasta entonces implicó un aumento del nivel de producción que excedía las necesidades inmediatas de las comunidades locales.

El registro arqueológico de los asentamientos permite reconocer en esta época dos tendencias claras: la producción intensificada y la jerarquización del territorio. Se constata el desarrollo de pequeñas granjas agrícolas en la parte más baja de los valles. Las manufacturas que se obtenían en los talleres de los oppida y la adquisición de importaciones estimuló a los campesinos a producir excedentes alimenticios. Allí donde han sido posibles excavaciones o prospecciones más o menos sistemáticas se distingue una importante concentración de la población y la evidencia de una artesanía especializada en la producción local de objetos: se generalizó el uso de la cerámica a torno y la metalurgia de hierro, a través de nuevos útiles como las hoces o la reja de arado, transformó la economía. Hay que reconocer que buena parte de la producción se movió dentro del ámbito doméstico y con especialistas a tiempo parcial. Sin embargo, la variabilidad y la gran cantidad

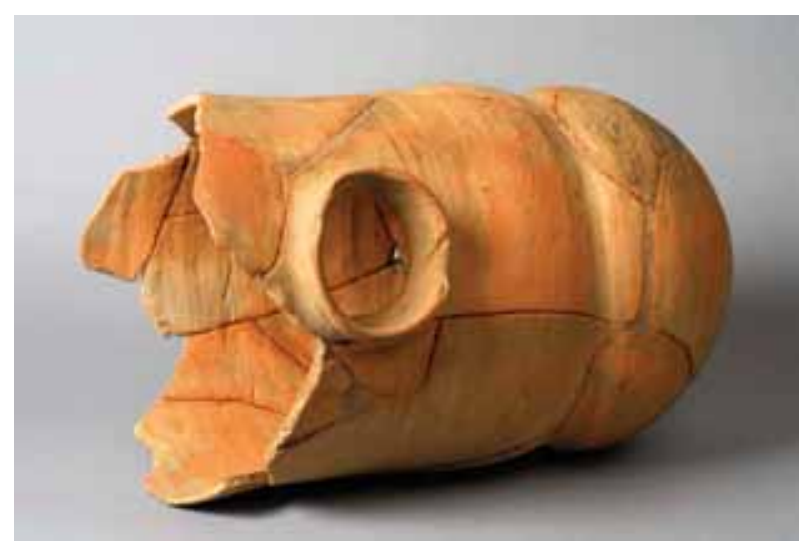

Figura 22.- Barrilete de tipo ibérico del oppidum de El Raso (Candeleda, Ávila) (foto de Mario Torquemada, Museo Arqueológico Regional, Madrid). 
de cerámica a torno presente en los yacimientos en las dos centurias previas al cambio de era, revela que algunas comunidades estuvieron inmersas en redes de intercambio que exigían una producción amplia y surtida (Fig. 22). No hay que perder de vista que en muchas ocasiones más que los recipientes en sí mismos lo que se está transportando es su contenido. La proximidad del ejército romano tuvo que crear un mercado inmediato; eso seguramente aportó un valor añadido a determinados recursos locales y requirió el empleo de talleres especializados. Por ejemplo, sabemos que el alfar del oppidum de Las Cogotas abarcaba en el siglo II a.C. un extenso complejo de dependencias y hornos de cerámica que ocupaban algo más de $300 \mathrm{~m} 2$ (Ruiz Zapatero y Álvarez-Sanchís 1995). Los hornos eran de tipo sencillo de una sola cámara y anexo al taller existía una gran dependencia que debió servir de almacén de productos acabados y como secadero de adobes para la construcción de casas y otras estructuras. Lo que interesa resaltar es que el taller de alfarería rebasa el ámbito de la producción doméstica tradicional y por sus dimensiones y la complejidad que implica su mantenimiento y su funcionamiento bien puede considerarse una actividad industrial a tiempo completo (Padilla 2010). Actividad que debió requerir especialistas, una producción estandarizada y una distribución de los productos cerámicos fuera del poblado. Toda la cerámica recuperada en el alfar fue realizada a torno y ofrece una variadísima colección de vasos, copas, cuencos, botellas, embudos (Salas 2008).... muchos de los cuales emparentan con los fabricados por las comunidades vettonas más occidentales (Las Merchanas, Yecla la Vieja, Pereña), dado que el ambiente material se fue haciendo cada vez más homogéneo en la región. Probablemente fue a partir de estos oppida como se distribuían las manufacturas a través de redes de intercambio.

Este fenómeno tuvo que tener también importantes implicaciones respecto a la forma utilizada por las comunidades indígenas para transmitir información o expresar identidades. Con anterioridad a la llegada de Roma, una parte muy importante de la cerámica se elaboraba a mano y se decoraba individualmente. Es evidente que distintos tipos de cerámicas y distintos tipos de motivos - como la cerámica a peine- codificaban información relativa a las personas, a su estatus, género o grupo familiar al que pertenecían. Con la fabricación industrial de la cerámica, la tipología y la decoración de los vasos cambiaron radicalmente. Existió una producción estandarizada y orientada a una distribución más amplia. No debería entonces resultar extraño que la forma de expresar identidades entre los vettones cambiara también de registro (Álvarez-Sanchís 2009: 150-154 y 2010). Nos faltan estudios en esa dirección. Lo mismo puede decirse respecto a la utilización de elementos de vestuario con arreglo a ciertos patrones estéticos. Como ha demostrado Gebhard (1991), la producción en masa de tipos muy específicos de fíbulas a finales de la Edad del Hierro en yacimientos centroeuropeos, frente a la acusada variabilidad y personalidad de estas joyas en épocas anteriores, sugiere que ahora jugaban un papel mucho menor a la hora de transmitir información sobre los individuos que las usaban y portaban.

El tamaño de algunos asentamientos y la envergadura de la producción hacen difícil no considerar estos oppida como los primeros centros urbanos (Collis 2000 y 2008). Una evidencia muy interesante es el hallazgo, en las proximidades de estos sitios o junto a las murallas, de extensas áreas formadas por acumulaciones de tierra cenicienta que incluyen fragmentos de huesos, escorias, adobes y cerámicas. Estos inmensos vertederos se formaron en el lapso de unas pocas generaciones y constituyen un rasgo singular de la cuenca del Duero (Sacristán et al. 1995: 349-350; Álvarez-Sanchís 1999: 151-153; Sanz et al. 2003: 59). Que este fenómeno aparezca sobre todo en asentamientos a partir de la primera mitad del siglo II a.C., podría considerarse resultado del desarrollo industrial alcanzado por estos centros a raíz de las demandas romanas. Su finalidad es difícil de determinar, puesto que en muchos casos la tierra ha sido arada y removida cientos de veces desde finales de la Edad del Hierro. Los vertederos de algunos oppida han proporcionado abundantes restos de adobe, cascotes y en general materiales para la construcción. Una posibilidad es que estos espacios fueran escombreras, es decir, sitios en los que se arrojaban los escombros procedentes de las reparaciones de las viviendas y los talleres (Sacristán et al. 1995: 349-350). Es posible incluso que estas 
reformas afectaran a manzanas o barrios completos de una ciudad. No hay que olvidar que muchos oppida crecieron de tamaño porque su riqueza debida a las manufacturas y al comercio atraía a gentes de las zonas de alrededor. Y, lógicamente, cuanta más gente se concentrara en estos sitios, más industrias, más productores de alimentos y más viviendas se hacían necesarios para poder alimentarlos y alojarlos (Wells 2002: 365 ss.). Hay otro factor que merece la pena tener también en cuenta. La importancia que tuvo la ganadería no hace descabellada la posibilidad de mercados de ganado o reuniones de la población en algunos oppida para transacciones comerciales y esparcimiento (Álvarez-Sanchís 1999: 153). Estos contactos serían un acicate a la hora de producir excedentes agrícolas y otros productos con vistas al intercambio. Semejantes reuniones contribuirían a esparcir restos de comida y otros detritus, incluyendo cerámica rota y huesos de animales. La acumulación de huesos en uno de los cenizales de Las Cogotas podría apuntar en este sentido, sobre todo si se tiene en cuenta su ubicación, en una de las zonas llanas y mejor protegidas del yacimiento (Ruiz Zapatero y Álvarez-Sanchís 1995: 222). En algunos de los sondeos anexos se encontraron hogares y huellas de acuñamientos de postes. Estos restos sugieren estructuras ligeras y no de larga y continuada ocupación que apoyarían la idea.

Salamanca fue otro oppidum importante donde se compraban e intercambiaban productos. Las excavaciones más recientes han sacado a la luz potentes cenizales con cerámicas, adobes, huesos y otros materiales, así como un edificio de adobe de planta rectangular, fechado en el siglo I a.C., asociado a varias plataformas que han sido interpretadas por sus excavadores como talleres destinados a la industria textil, alfarera e incluso a la molienda de cereales y bellotas (Misiego et al. 1998; Martín Valls 1999: 215; Alario y Macarro 2007: 216 ss.). Hay que ver como un hecho lógico la función comercial que debió desempeñar la ciudad, muy beneficiada al situarse en la frontera de dos paisajes completamente diferentes, la cuenca miocénica de la Armuña, de vocación agrícola, y la penillanura salmantina, típicamente ganadera. El sitio es también especial por su situación respecto a las rutas de comunicación. Se encuentra junto a un vado del río
Tormes y en una de las rutas terrestres más importantes del oeste peninsular, de dirección norte-sur, la vieja ruta tartésica que andando el tiempo se convertiría en la calzada romana de la Plata (Gillani y Santonja 2007). Los bienes tenían que cruzar forzosamente este territorio para llegar al norte del país, lo que enriqueció a la aristocracia que controlaba ese tránsito. En la ciudad salmantina vivía y trabajaba una importante población que se sentía protegida.

Gran parte de los oppida vettones estaban rodeados de murallas hechas de piedra, tierra, adobe y madera, y eran mucho mayores que los asentamientos de las épocas anteriores. Aunque sólo unos pocos han sido excavados, todo parece indicar que durante la conquista romana se levantaron nuevas murallas, bastante distintas a las tradicionales, empleando entre otras novedades paramentos de grandes piedras, sofisticadas puertas de entrada con complejos sistemas de acceso para su mejor protección y torres de planta cuadrada o rectangular (Álvarez-Sanchís 2007b; González-Tablas 2009). Algunos de estos rasgos pueden apreciarse todavía hoy en el recinto más moderno -el tercero- de La Mesa de Miranda y también en Ulaca. Existen evidencias de un rápido crecimiento en Las Cogotas y Salamanca - por lo menos de espacio ocupado y defendido- y buenos ejemplos de ciudades creadas prácticamente ex novo. Como El Raso (Candeleda), al otro lado del Sistema Central, cuyas defensas parece que se erigieron a comienzos del siglo II a.C. (Fig. 23). Este interesantísimo sitio conserva en la actualidad restos de una docena de torres y una superficie aproximada de unas 20 hectáreas. Sucede en el tiempo a otro yacimiento próximo conocido con el nombre de El Castañar, una pequeña aldea no fortificada que se ha relacionado con el famoso cementerio de incineración de la Segunda Edad del Hierro (Fernández Gómez 1995: 154-155). Esta necrópolis demuestra que ya existía una comunidad en los alrededores antes del año 200 a.C., que experimentó un rápido crecimiento y no un desarrollo paulatino.

El oppidum de Ulaca, junto a la sierra de Gredos, en el corazón del territorio vettón, floreció aproximadamente entre el 300 a.C. y el cambio de era (Figs. 24 y 25). Basándonos en el tamaño de las zonas amuralladas, en los restos de estructuras monumentales, en la planta de las vivien- 


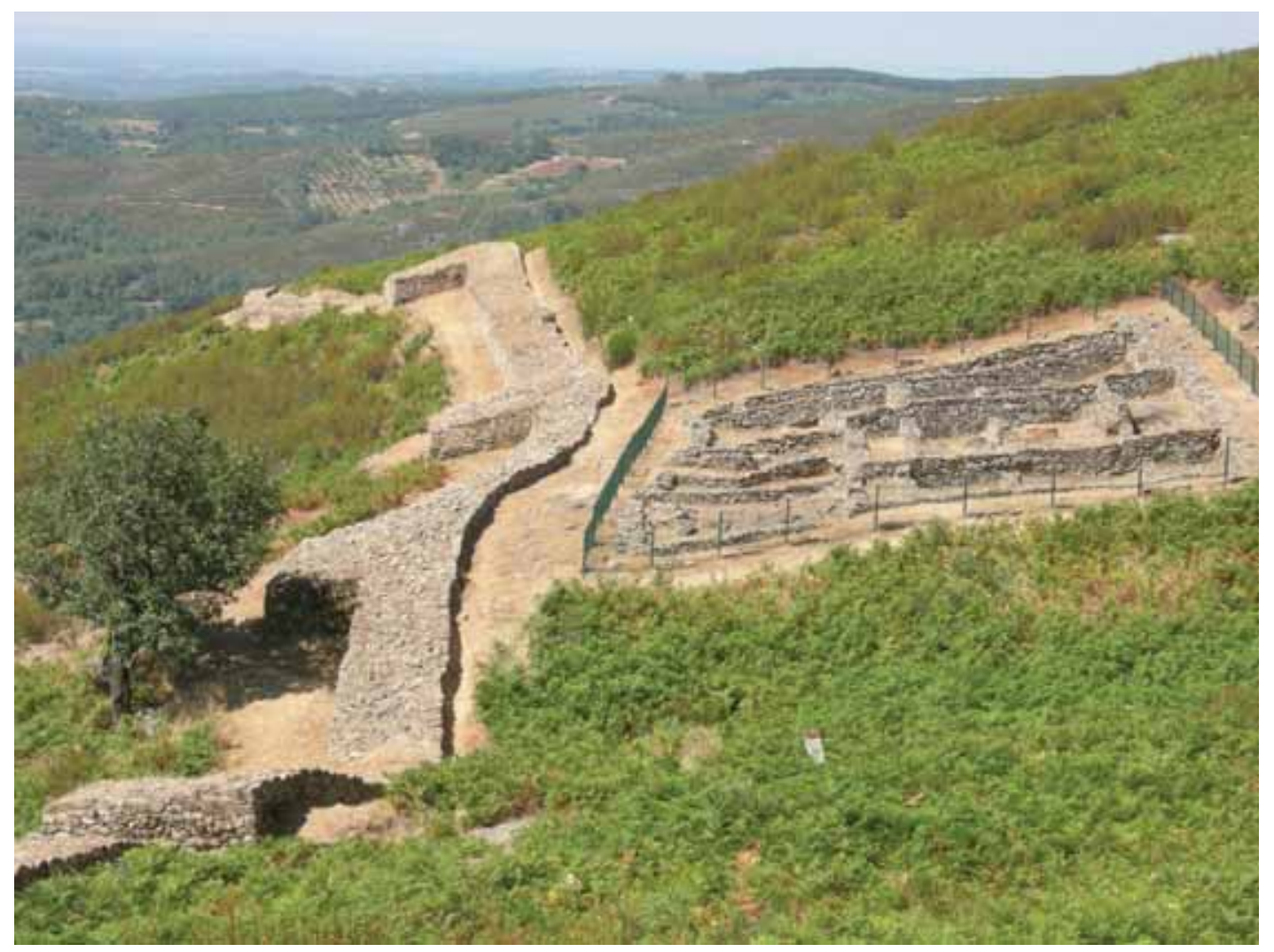

Figura 23.- Muralla sur del oppidum de El Raso y sector de casas excavadas.

das y en la densidad de los materiales hallados en superficie, parece que el poblado estaba dividido en sectores o barrios diferenciados (Álvarez-Sanchís 1999: 144; Ruiz Zapatero 2005). La prospección de este inmenso asentamiento reveló, entre otras muchas cosas, la existencia de varias canteras para la extracción de bloques de granito. El sistema tradicional consistía en seguir las vetas y fracturas naturales, rompiendo con cuñas de hierro y madera bloques de tamaños más o menos estandarizados. Una de las canteras tuvo que destinarse a la obtención de material constructivo para las viviendas, y al menos otra -la más próxima a la muralla por el lado sur- parece que estuvo relacionada con la obtención de grandes sillares para la construcción de las defensas. El trabajo de la piedra debió ser muy intensivo (Rodríguez Hernández 2009). Sondeos llevados a cabo en la ladera baja del asentamiento permitieron localizar y excavar una tumba de empedrado tumular con un interesante ajuar metálico y cerámico datado a finales de la Edad del Hierro (ÁlvarezSanchís et al. 2008). Trabajos posteriores han deparado el hallazgo de nuevas tumbas en la misma zona. Además, los enterramientos se localizan en un área que anteriormente fue utilizada para albergar un interesante conjunto de talleres artesanales, dato que revela una organización del oppidum bastante más compleja de lo habitualmente pensado (Ruiz Zapatero 2005: 36).

La ciudad abarcaba una superficie de más de 70 hectáreas que no debía estar sólo relacionada con el tamaño de la comunidad residente,

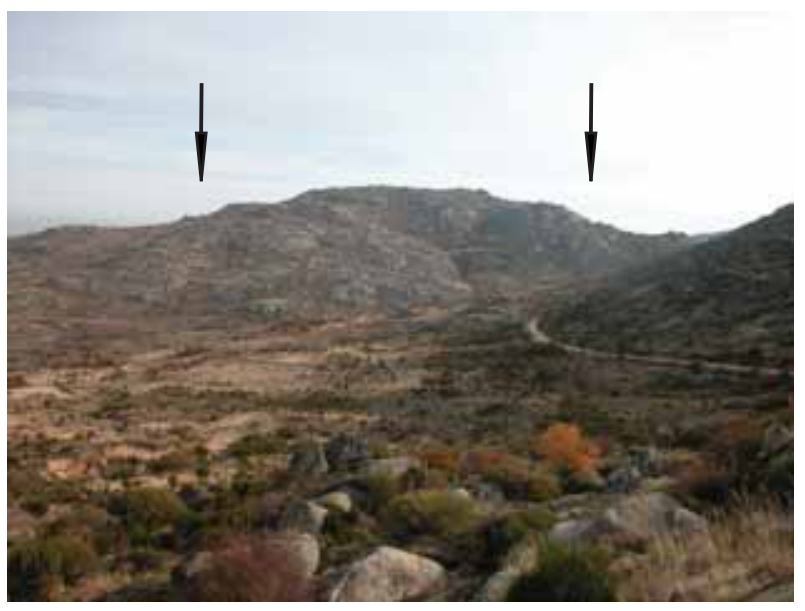

Figura 24.- Vista general del oppidum de Ulaca, desde el noreste (foto de M. Almagro-Gorbea). 


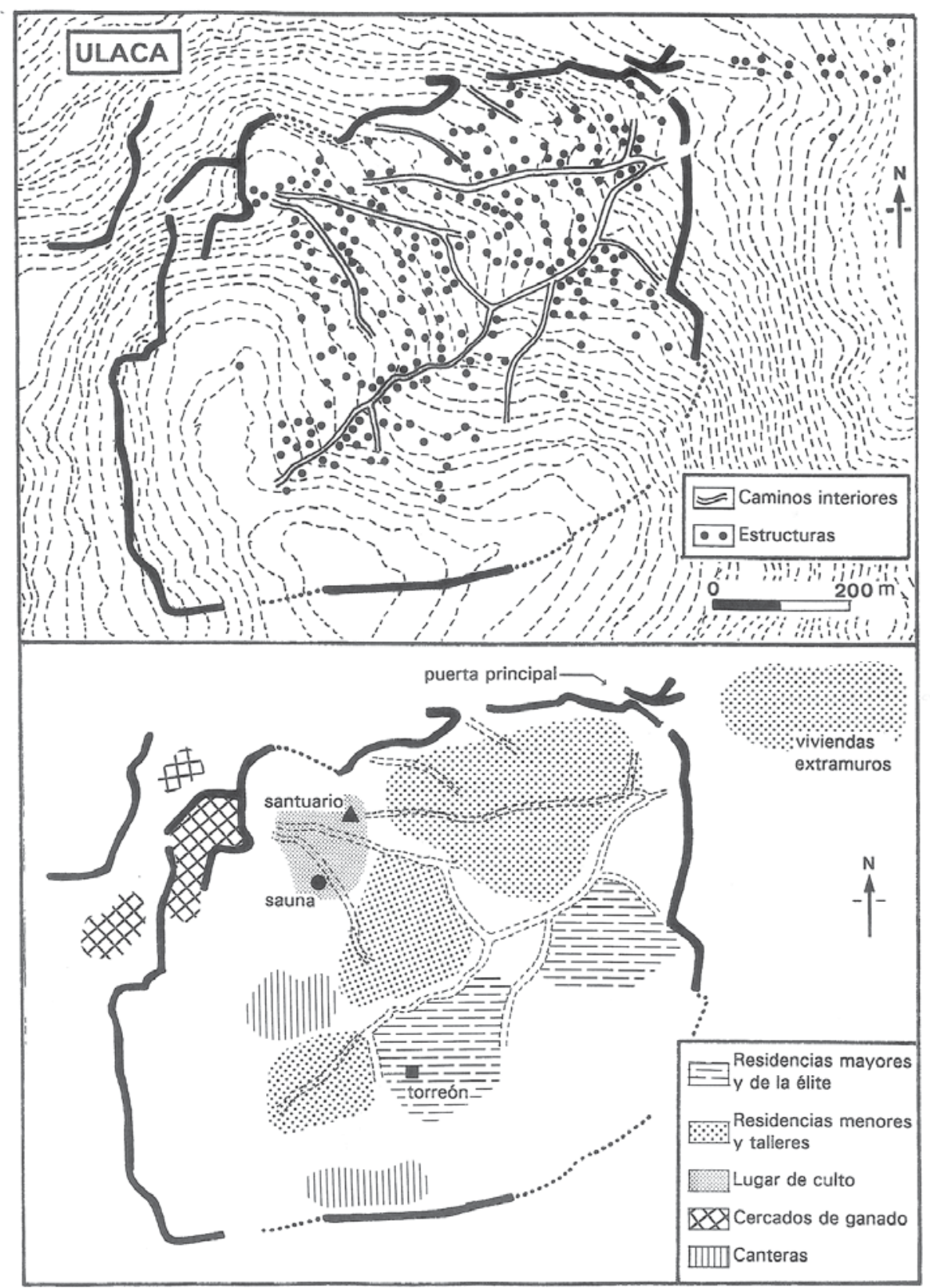

Figura 25.- Plano, topografía y organización interna de Ulaca (Álvarez-Sanchís 1999).

aunque ésta rebasara en algún momento de su existencia los dos millares de almas. Como en muchos otros oppida hispanos y de la Europa bárbara en general, la adaptación a la topografía imponía en parte la superficie que debía ser amurallada (Audouze y Büchsenschutz 1989: 110), por lo que algunas zonas del asentamiendo parece que estuvieron prácticamente deshabitadas. Otra motivación importante pudo ser la de reservar extensas áreas para pastos y cuidado de los ganados. Todo eso sin olvidar que la presencia romana creará nuevas condiciones para la organización de las luchas armadas y la defensa de las fortificaciones por parte de las tribus indígenas (Esparza 2003; Ruiz Zapatero 2003: 14), entre otras razones porque las legiones manejaban máquinas de asalto -torres, arietes, piezas de artillería- hasta entonces desconocidas en el interior de la Península Ibérica. De ahí que una parte de los asentamientos, o de las reformas llevadas a cabo, pudieron establecerse por razones defensivas. En los momentos de conflicto la población de alrededor podría refugiarse dentro de los oppida, ya que existiría espacio libre suficiente. Aunque el comercio y la guerra 


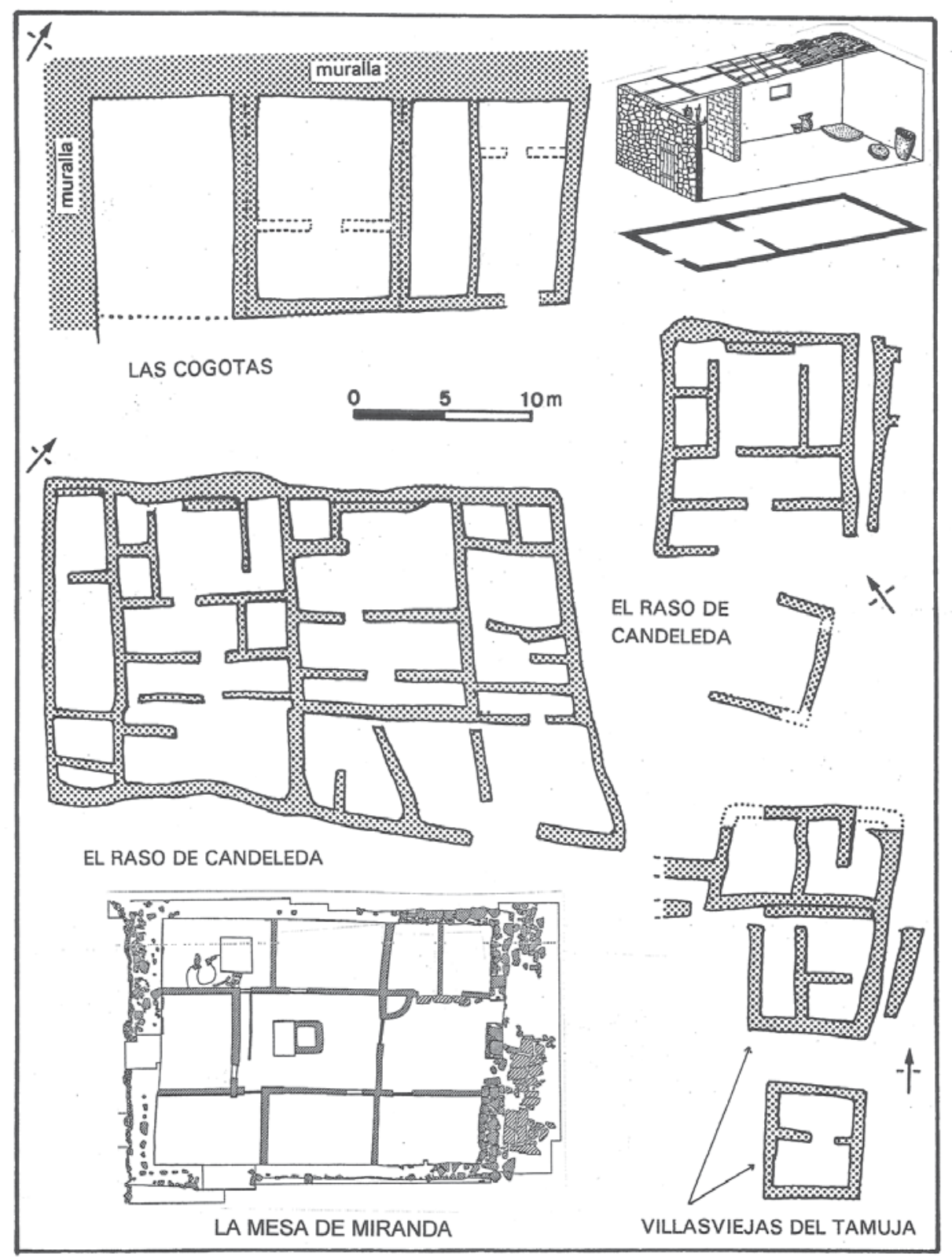

Figura 26.- Plantas de casas excavadas de Las Cogotas, El Raso, Villasviejas del Tamuja y La Mesa de Miranda (a partir de Álvarez-Sanchís 1999, Fernández Gómez 1986, Hernández 1989 y González-Tablas 2009).

fueron dos factores importantes en el desarrollo de estos centros a finales de la Edad del Hierro (Wells 2002: 365 ss.), la construcción de algunas defensas también pudo estar motivada, como ha señalado Collis (1984: 107), por razones internas, entre otras cosas para vigilar el tráfico de mercancías. El oppidum de Ulaca alberga en este sentido un importante edificio, de gran aparejo y estructura turriforme $(14 \times 10 \mathrm{~m})$, que podría haber servido de atalaya, controlando de hecho una enorme extensión del área habitada, y por tanto el trasiego de carros, gentes y productos.
Las viviendas tienen planta cuadrada o rectangular, entre 50 y $150 \mathrm{~m} 2$ de superficie interna, divididas en tres o cuatro estancias (Fig. 26). La primera era la más importante, con el hogar y en ocasiones el banco adosado a la pared. Ocupa aproximadamente la mitad del espacio habitable y a ella se accede directamente desde la puerta exterior. Las otras habitaciones harían de despensa -donde se depositaban los grandes recipientes de cerámica o los aperos de labranza- y dormitorio; éstas pueden aparecer contiguas a la primera o dispuestas ordenadamente en torno a un eje 


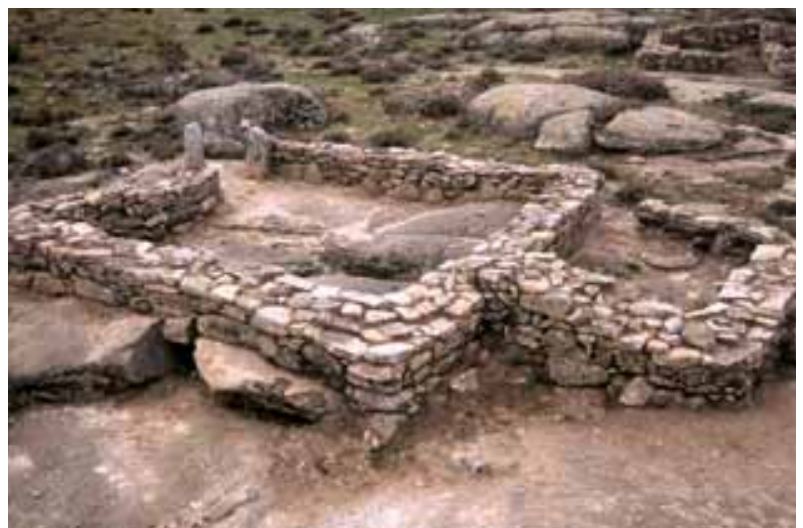

Figura 27.- Viviendas excavadas del poblado de Ulaca (foto de F. Fabián).

longitudinal. Es común la utilización de muros con zócalos de piedra que se recrecían con barro o adobe. Otras veces debieron de ser exclusivamente de piedra -pizarra o granitohasta conectar con la cubierta. El hallazgo de bloques de barro con improntas de maderos cilíndricos sugiere que las cubiertas estarían construidas con troncos de árbol, recubiertos de barro y paja. En época tardía se produjeron algunos cambios en la arquitectura doméstica, seguramente como consecuencia de la influencia romana (Martín Valls y Esparza 1992: 275; González-Tablas 2008 y 2009: 72 ss.; López García 2011) (Figs. 27 y 28). Los ejemplos más claros los encontramos en La Mesa de Miranda, Ulaca y El Raso; allí se han detectado grupos de viviendas extensas $(>400 \mathrm{~m} 2)$ adosadas unas a otras -sin que podamos establecer con claridad su sistema organizativo- y el recurso a emplear grandes sillares en los zócalos. La organización del espacio doméstico podría reflejar la exteriorización de diferencias sociales -como veíamos en los ajuares de las tumbas- pero también funcionalidades diferentes, no estrictamente de habitación.

Hablar en los oppida vettones de urbanismo en sentido estricto no es fácil. Pero cuando abordamos su organización interna hay una lógica espacial: barrios residenciales con distintos niveles de riqueza, casas extramuros con equipos domésticos más pobres, áreas de encerramiento de ganado, áreas industriales (alfares, talleres metalúrgicos, canteras), vertederos, sitios para el intercambio y el esparcimiento, áreas de culto, etc. Las viviendas son más amplias y complejas que las cono- cidas con anterioridad, y eso responde seguramente a una organización doméstica más especializada.

\subsection{Las ciudades romanas y los oppida}

En el siglo I a.C. la relación entre las demandas romanas, el aumento de la producción y el desarrollo de los oppida era evidente. Las condiciones generales de vida empezaban a cambiar en muchos aspectos desde la Edad del Hierro. La población era mayor que antes de la conquista y las ciudades empezaban también a ser mayores y más complejas que los asentamientos precedentes. La actividad de estos sitios sería un reclamo para las comarcas de alrededor. La acumulación de riqueza atraería a más y más personas y eso mismo tuvo que desestabilizar gravemente las relaciones familiares y las relaciones de propiedad. Las diferencias sociales dejaron de estar tan marcadas en los cementerios y pasaron a ser mucho más visibles en los asentamientos. Por primera vez se enterraron numerosos depósitos de metales, sobre todo en forma de vajillas, joyas y monedas (Delibes y Esparza 1989; Delibes et al. 1993; Cuesta et al. 2010). Buena parte de los depósitos que conocemos aparecían guardados en recipientes en el interior de las casas o en las inmediaciones de los poblados. Por ejemplo, un importante depósito que contenía denarios ibéricos se encontró en el centro histórico de Salamanca. Entre otras cosas, el hallazgo se ha relacionado con la inseguridad reinante du-

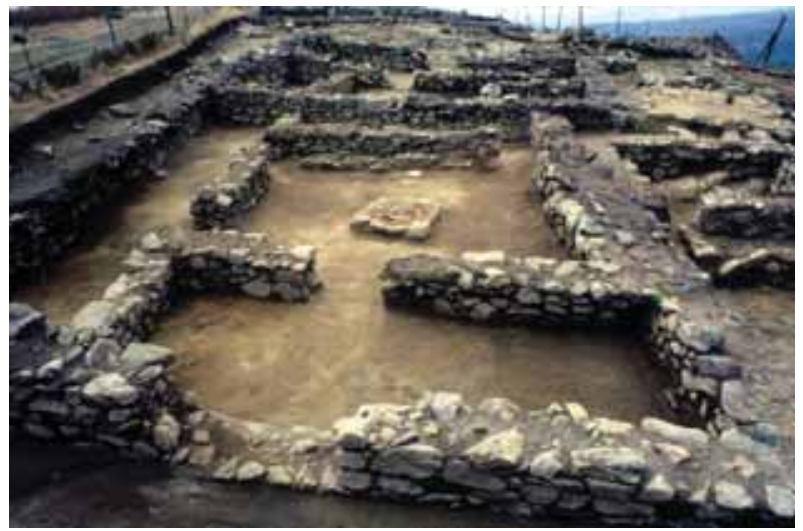

Figura 28.- Viviendas excavadas del poblado de El Raso, con el hogar en el centro de la estancia principal (foto de F. Fernández Gómez). 


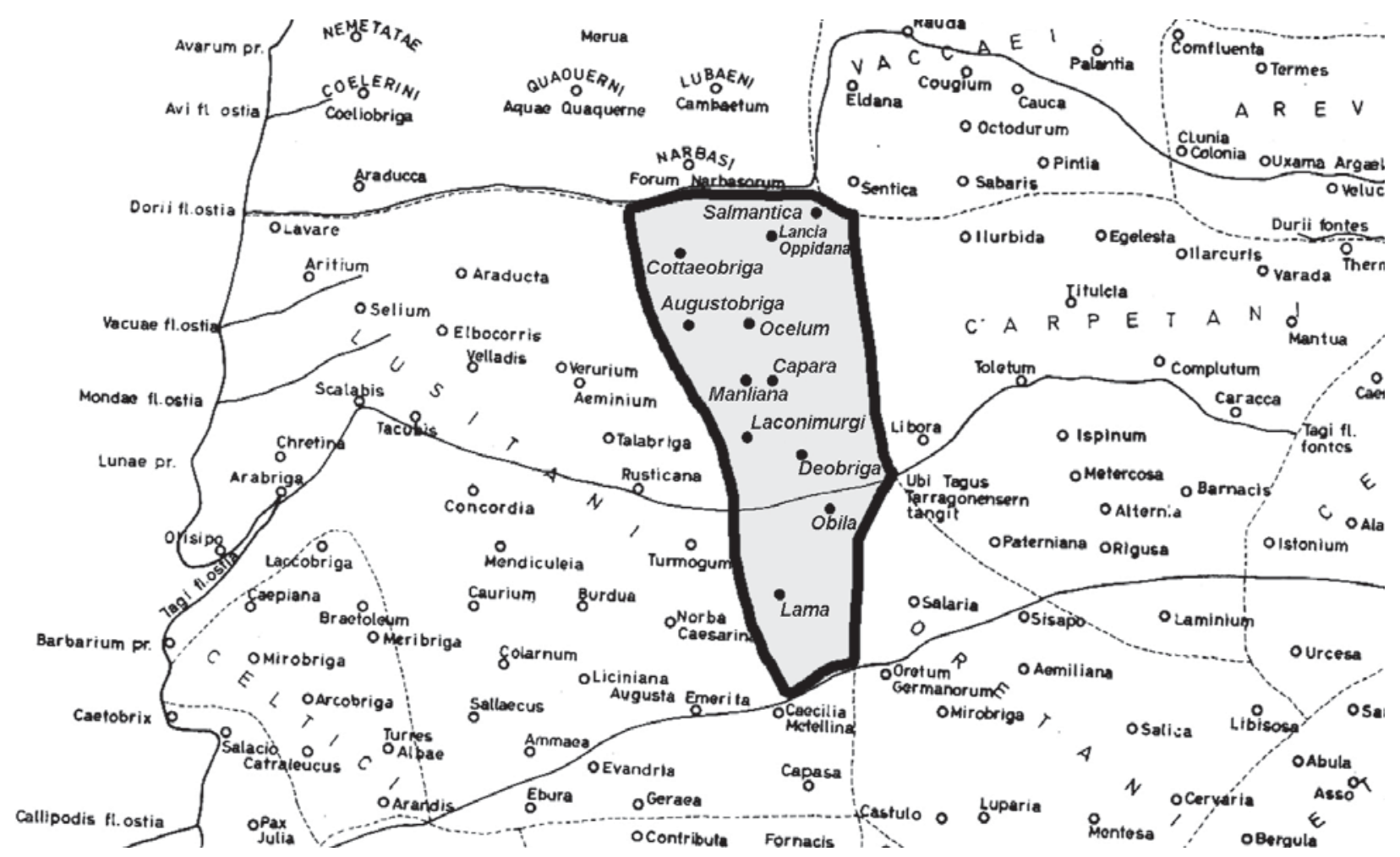

Figura 29.- La Vettonia según Ptolomeo (Domínguez Monedero 2008).

rante el primer cuarto del siglo I a.C. Más al sur, en el oppidum de El Raso, las excavaciones han proporcionado denarios y ases republicanos así como un singular tesorillo que estaba oculto en una de las viviendas, cuyas fechas de acuñación permitirían situar el abandono del poblado en la década de los años cuarenta del siglo I a.C. (Fernández Gómez 1986: 444-448), por tanto durante los conflictos civiles entre los partidarios de César y Pompeyo. La rica orfebrería indígena encontrada en algunos castros zamoranos -Arrabalde, Ramallas, San Martín de Torres- era seguramente otra forma de exhibir el lujo que proporcionaba la riqueza (Delibes et al. 1996). Se enterró coincidiendo con la instalación en Rosinos de Vidriales de una legión romana, la $X$ Gemina, que hay que vincular con el desarrollo de las operaciones contra cántabros y astures en los años 29-19 a.C.

Es inevitable relacionar estas ocultaciones con tiempos de guerra, pero no hay que descartar otras posibilidades. Los arqueólogos tendemos a simplificar demasiado el significado y la función de los contextos arqueológicos -ya se trate de un poblado, una vivienda, un cementerio o un santuario- sin tener en cuenta que muchos sitios y lugares de hábitat pudieron tener múltiples funciones para las gentes de la Edad del Hierro (Wells 2002: 377). Cualquiera que haya sido la causa específica de su ocultación, lo cierto es que estos atesoramientos constituían excedentes de riqueza disponibles, es decir, un capital importante reunido por una o varias personas y puesto a buen recaudo. Desde el siglo V a.C. los hispanos que habían servido como mercenarios en los ejércitos mediterráneos se familiarizaron con la moneda como sistema de pago. Es verdad que no llegó a existir una auténtica economía monetaria, es más, ni siquiera conocemos acuñaciones de moneda en las ciudades de la Meseta occidental durante la Edad del Hierro, pero es indudable que en los dos últimos siglos antes del cambio de era las monedas se convirtieron en un medio importante para almacenar y atesorar riqueza. De esta forma, las relaciones entre los individuos pudieron cambiar. Era el mercado el que determinaba el valor de los productos y no las relaciones sociales o familiares. Este sistema de acaparación y disfrute de la riqueza sustituyó al característico armamento de las necrópolis como símbolo social.

El crecimiento demográfico y el espectacular desarrollo experimentado por algunos asen- 
tamientos en esta época se ha relacionado también con fenómenos de "sinecismo" (AlmagroGorbea 1994), es decir, ciudades que aglutinan en muy pocos años importantes contingentes de población llegada de fuera. Estas migraciones exigirían importantes recursos para movilizar y mantener grupos suficientemente numerosos. En el valle Amblés, el proceso de la despoblación de algunos castros se observa con relativa claridad. Apenas existen testimonios de época tardía en Las Cogotas y algo análogo ocurre en La Mesa de Miranda. El tercer recinto del oppidum se levantó en un momento impreciso del siglo II a.C., pero lo cierto es que la nueva muralla, que invadía una parte del cementerio, no llegó nunca a terminarse. Tal ampliación pudo deberse a un momento de inseguridad. Tradicionalmente se ha enfatizado el papel de las guerras que ocasiona la conquista romana (Martín Valls 1986-87: 81-82; Fabián 2005: 20 ss.), pero lo cierto es que apenas hay datos sobre las rutas seguidas por las legiones. La población pudo trasladarse al vecino oppidum de Ulaca (González-Tablas 2009: 78), donde algunos vestigios de época tardía, como cerámicas pintadas y varios denarios de la ceca de arekorata y sekobirices (Álvarez-Sanchís et al. 2008: 347), podrían llevarse a comienzos del siglo I a.C., cronología que encaja muy bien con la fase final de la ciudad.

En el extremo suroccidental, en tierras cacereñas, tenemos un ejemplo excepcional. La presencia de una ceca celtibérica, Tamusia, en el castro de Villasviejas del Tamuja (Botija, Cáceres), con emisiones de moneda que se llevan al primer cuarto del siglo I a.C. (Blázquez 1995), demuestra inequívocamente un desplazamiento de gentes a través de la Meseta -cruzando el Tajo- en dirección sur. Uno de los cementerios del castro se fecha en los siglos II-I a.C. y confirma la presencia de puñales biglobulares y otras armas de hierro que seguramente procedan de la Meseta oriental (Hernández et al. 2008). La publicación de una supuesta tésera de bronce con la leyenda hispanocelta escrita en caracteres latinos AVILACA, hallada cerca del castro citado pero que procedería de la Ávila prerromana identificada con el yacimiento de Ulaca (Rodríguez Morales 2009), aporta un nuevo e interesante testimonio a esta fase final de los oppida. No obstante, la ubicación actual de la pieza es desconocida y su estudio requiere de nuevas valoraciones. También tenemos evidencias de otros aportes étnicos en el $\mathrm{SO}$ de origen meseteño (Berrocal-Rangel 1992; Almagro-Gorbea y Torres 1999: 109-116), tal vez en forma de pequeños grupos (Lorrio y Ruiz Zapatero 2005). Estos procesos pudieron desarrollarse con matices diferenciados según las comarcas. Quedan, sin embargo, muchos detalles por entender. Del castro extremeño de Alcántara procede un interesante bronce que reproduce un pacto firmado el 104 a.C. entre los romanos y el pueblo de los Seano [rum?] (López Melero et al. 1984). Se trata de un acuerdo firmado con un populus y no con un oppidum, indicio de que el poblamiento en algunas zonas aún no había alcanzado el grado de desarrollo propio de una organización urbana, allí donde la ciudad adquiere entidad y autonomía suficiente para poder representar al territorio (Martín Bravo 1999: 263-264). Episodios como éste resultan fundamentales porque revelan el enfrentamiento de Roma a comunidades dispersas en granjas y aldeas. Los oppida seguían siendo excepcionales, y la inmensa mayoría de la gente seguía viviendo en pequeños asentamientos.

El sistema que acabamos de bosquejar empezó a desintegrarse en la segunda mitad del siglo I a.C. La conquista puso fin a la economía indígena y a su organización política, y la sustituyó por el centralismo romano (Salinas 2001). Se crearon ciudades y campamentos, se trazaron caminos de piedra para garantizar el tráfico comercial y militar y se construyeron puentes para cruzar ríos (Gillani y Santonja 2007). La red de comunicaciones obligó a las comunidades indígenas a moverse por el territorio de una manera diferente a como lo habían hecho hasta entonces. Las tropas estacionadas requerían ingentes cantidades de comida y recursos. Esta demanda no sólo estimuló altos niveles de producción por parte de la población campesina. Uno de los aspectos más destacables desde el punto de vista de los patrones de asentamiento, es la creciente importancia de las ciudades emplazadas en tierras aptas para el cultivo del cereal, o bien en zonas de extracción de hierro, estaño y cobre. Si bien la ecuación entre demanda romana de productos alimenticios y materias primas $=$ intensificación de la pro- 
ducción agrícola y minera, es una explicación demasiado sencilla, al menos tiene la virtud de poner de relieve la influencia de un factor importante en la organización del territorio observable en este sector de la Meseta.

Algunos oppida sobrevivieron como ciudades romanas. Los modelos de cambio se documentan bastante bien: ciudades como Salmantica (Salamanca), Obila (Ávila), Augustobriga (Talavera la Vieja), Lacimurgi (Navalvillar de Pela), Bletisama (Ledesma), Mirobriga (Ciudad Rodrigo), Turgalium (Trujillo), Caesarobriga (Talavera de la Reina) o Urunia (Irueña, en Fuenteguinaldo) -citando sólo algunos casos cuyos nombres antiguos nos son conocidos por las fuentes y es posible identificar- muestran continuidad entre los tiempos prehistóricos y el período romano. La clave estaba en buscar emplazamientos acordes con los intereses romanos, valorando los recursos agrícolas y mineros del territorio y el acceso de la población a las redes de intercambio controladas por el ejército. La información que da Ptolomeo (II, 5, 7) de éstas y otras ciudades es importante para valorar la amplitud del territorio vettón en época altoimperial (Fig. 29) y el nuevo modelo urbano propiciado por Roma (Domínguez Monedero 2008: 376), máxime cuando, como sabemos a partir de algunos testimonios epigráficos, la provincia Lusitania se divide en dos circunscripciones -Lusitania y Vettonia- a cuyo frente había un procurator (Salinas 2001: 84-87). La elite autóctona pronto sacó partido de la ocupación y el oeste de la región conoce en está época un relativo proceso de urbanización (Martín Valls et al. 1991: 159). La potenciación de algunos asentamientos en esta época se plasma, por ejemplo, en los términos augustales erigidos en el año 6 d.C. para fijar los límites territoriales entre varias ciudades de la actual provincia de Salamanca (Salmantica, Bletisama, Mirobriga,
Valuta, Polibeda), que hacen pensar en su temprana conversión en municipios romanos. Las excavaciones efectuadas para restaurar la puerta occidental de Yecla la Vieja y la meridional de Las Merchanas han ofrecido datos muy elocuentes sobre la vitalidad y evolución de algunos asentamientos al oeste de Salamanca (Benet y López Jiménez 2008: 174-175), un territorio que atrajo a gentes de distinta procedencia - como pone de manifiesto su nutrida epigrafía (Martín Valls 1982) - y que sin duda hay que relacionar con las explotaciones mineras. Otros oppida no sobrevivieron como asentamientos romanos, su población declinó, así como sus actividades económicas. Lugares emblemáticos como Las Cogotas, La Mesa de Miranda, El Raso o la misma Ulaca, fueron abandonados. En el valle Amblés, sabemos que Ávila desempeñará un papel clave en la vertebración del territorio en época altoimperial (Mariné 1995). Los materiales recuperados atestiguan que desde finales del siglo I a.C. existió en el lugar, dominando el paso del río Adaja, un centro de considerable importancia nutrido a partir de los viejos núcleos indígenas (Quintana et al. 20032004; Fabián 2007: 88 ss.).

El problema de los orígenes de los oppida que Roma llegó a conocer en la Meseta comienza a situarse hoy en un punto álgido, y desde luego puede afirmarse que no siempre existe unanimidad de criterios por parte de los especialistas a la hora de ofrecer una visión de conjunto. Pero lo cierto es que, desde una perspectiva arqueológica de "tiempos largos" -como atinadamente señalaba el profesor Martín Valls hace ya cinco lustros- interesa mucho más estudiar el proceso a través del cual pequeños poblados se convirtieron en grandes ciudades en vísperas de la conquista romana, que el que éstos correspondan a los vacceos, arévacos, lusitanos o los propios vettones.

\section{REFERENCIAS BIBLIOGRÁFICAS}

AcsÂDI, G.; NemÈskerI, J. (1970): History of Human Life Span and Mortality. Budapest.

Adouze, F. ; Buchsenschutz, O. (1989): Villes, villages et campagnes de l'Europe Celtique. Paris.

Alario, C.; Macarro, C. (2007): La ciudad hispano-romana de Salmantica a partir de la secuencia estratigráfica del solar del Trilingüe. Arqueología en la Vía de la Plata (Salamanca) (G. Gillani, M. Santonja, eds.), Ediciones de la Fundación Premysa, Colección gentes y paisajes, Salamanca. 
Alföldy, A. (1995): Inscripciones, sacrificios y misterios: el santuario rupestre de Panoias/Portugal. Informe preliminar. Madrider Mitteilungen, 36: 252-258.

Almagro-Gorbea, M. (1994): Urbanismo de la Hispania "céltica. Castros y Oppida del centro y occidente de la Península Ibérica. Castros y Oppida en Extremadura (M. Almagro-Gorbea, A. Ma . Martín, eds.), Complutum Extra, 4, Madrid: 13-75.

Almagro-Gorbea, M. (2008): Celtas y Vettones. Arqueología Vettona. La Meseta Occidental en la Edad del Hierro (J. Álvarez-Sanchís, ed.), Zona Arqueológica, 12, Museo Arqueológico Regional, Alcalá de Henares: 44-60.

Almagro-Gorbea, M. (2009): Lusitanos y Vettones. Lusitanos y Vettones. Los pueblos prerromanos en la actual demarcación Beira Baixa - Alto Alentejo - Cáceres (P. J. Sanabria, ed.), Memorias, 9, Museo de Cáceres: $15-43$.

Almagro-Gorbea, M.; Álvarez Sanchís, J. (1993): La sauna de Ulaca: Saunas y baños iniciáticos en el mundo céltico. Cuadernos de Arqueología de la Universidad de Navarra, 1:177-232.

Almagro-Gorbea, M. ; Lorrio, A. (1991): Les Celtes de la Péninsule Ibérique au IIIème siècle av. J.-C. Actes du IX Congrès International d'études celtiques (Paris 1991), première partie: Les Celtes au III siècle avant J.-C., Etudes Celtiques, XXVIII: 33-46.

Almagro-Gorbea, M.; Torres, M. (1999): Las fíbulas de jinete y de caballito. Aproximación a las élites ecuestres y su expansión en la Hispania Céltica. Institución Fernando el Católico, Zaragoza.

Álvarez-Sanchís, J. R. (1999): Los Vettones. Bibliotheca Archaeologica Hispana, 1, Real Academia de la Historia, Madrid.

Álvarez-Sanchís, J. R. (2003a): La Edad del Hierro en la Meseta Occidental. Madrider Mitteilungen, 44: 346-386.

Álvarez-Sanchís, J. R. (2003b): Los Señores del Ganado. Arqueología de los pueblos prerromanos en el occidente de Iberia. Akal, Madrid.

Álvarez-Sanchís, J. R. (2005): De aldeas a ciudades. Celtíberos. Tras la estela de Numancia (A. Jimeno, ed.), Junta de Castilla y León, Soria: 73-81.

Álvarez-Sanchís, J. R. (2007a): Castros y aldeas. Los vettones en el valle medio del Tajo. Prehistoria y Protohistoria de la Meseta Sur (Castilla-La Mancha) (J. Pereira, coord.), Almud, Ediciones de Castilla-La Mancha, Ciudad Real: 199-216.

Álvarez-Sanchís, J. R. (2007b): El poblado fortificado de La Mesa de Miranda (Chamartín, Ávila) y su relación con el poblamiento prerromano del valle Amblés. Paisajes fortificados de la Edad del Hierro. Las murallas protohistóricas de la Meseta y la vertiente atlántica en su contexto europeo (L. BerrocalRangel, P. Moret, eds.), Bibliotheca Archaeologica Hispana, 28, Real Academia de la Historia-Casa de Velázquez, Madrid: 237-254.

Álvarez-SANChís, J. R. (2008): El descubrimiento de los vettones. Las Cogotas y la cultura de los verracos. Arqueología Vettona. La Meseta occidental en la Edad del Hierro (J. Álvarez-Sanchís, ed.), Zona Arqueológica, 12, Museo Arqueológico Regional, Alcalá de Henares: 14-42.

Álvarez-Sanchís, J. R. (2009): Expresiones de identidad: las comunidades prerromanas de la Meseta. $A r-$ queología Espacial: Identidades. Homenaje a $M^{a}$ Dolores Fernández-Posse (I. Sastre, coord.), Arqueología Espacial, 27: 145-156.

Álvarez-Sanchís, J. R. (2010): La cerámica con decoración a peine: de "fósil guía" a indicador de etnicidad. De la Región Vaccea a la Arqueología Vaccea (F. Romero, C. Sanz, eds.), Vaccea Monografías, 4, Valladolid: 293-318.

Álvarez-Sanchís, J. R.; Marín, C.; Falquina, A.; Ruiz Zapatero, G. (2008): El oppidum vettón de Ulaca (Solosancho, Ávila) y su necrópolis. Arqueología Vettona. La Meseta Occidental en la Edad del Hierro (J. Álvarez-Sanchís, ed.), Zona Arqueológica, 12, Museo Arqueológico Regional, Alcalá de Henares: 338-361.

Álvarez-Sanchís, J. R.; Ruiz Zapatero, G. (1999): Paisajes de la Edad del Hierro: Pastos, ganado y esculturas en el valle de Amblés (Avila). II Congreso de Arqueología Peninsular (R. Balbín, P. Bueno, eds.), Zamora: 313-323. 
Álvarez-SAnChís, J. R.; Ruiz Zapatero, G. (2001): Cementerios y asentamientos: bases para una demografía arqueológica de la Meseta en la Edad del Hierro. Entre Celtas e Iberos. Las poblaciones protohistóricas de las Galias e Hispania (L. Berrocal-Rangel, Ph. Gardes, eds.), Bibliotheca Archaeologica Hispana, 8, Real Academia de la Historia, Madrid: 61-75.

Álvarez-Sanchís, J. R.; Ruiz Zapatero, G.; Lorrio, A.; Benito-López, J. E.; Alonso Hernández, P. (1998): Las Cogotas: anatomía de un oppidum vettón. Homenaje a Sonsoles Paradinas (M. Mariné, E. Terés, coords.), Múseo de Ávila: 73-94.

Arnold, B.; Wicker, N.L. (2001): Gender and the Archaeology of Death. Altamira Press, Walnut Creek.

Balter, M. (1995): Masters and slaves in an Iron Age Cave? Science, 268: 1132-1133.

BAQUEDANO, I. (1996): Elementos de filiación mediterránea en Ávila durante la I y II Edad del Hierro. Boletín de la Asociación Española de Amigos de la Arqueología, 36: 73-90.

Baquedano, I.; Escorza, C. M. (1998): Alineaciones astronómicas en la necrópolis de La Osera (Chamartín de la Sierra, Ávila). Complutum, 9: 85-100.

Baquedano, I.; Escorza, C. M. (2009): Orientaciones astronómicas en las necrópolis tumulares de La Osera (Ávila) y El Cigarralero (Murcia). Arqueoastronomía (M. Cerdeño, G. Rodríguez Caderot, eds.), Complutum, 20 (2): 121-140.

Benet, N.; JimÉnez, M.C.; Rodríguez, M.B. (1991): Arqueología en Ledesma, una aproximación: La excavación en la Plaza de San Martín. Del Paleolítico a la Historia (M. Santonja, coord.), Junta de Castilla y León y Museo de Salamanca, Salamanca: 117-136.

BenEt, N.; LÓPEZ JimÉnEz, O. (2008): Investigaciones recientes en la Edad del Hierro en Salamanca y la Beira Alta: los castros del occidente. Arqueología Vettona. La Meseta Occidental en la Edad del Hierro, (J. Álvarez-Sanchís, ed.), Zona Arqueológica, 12, Museo Arqueológico Regional, Alcalá de Henares: 162-181.

Berrocal-Rangel, L. (1992): Los pueblos célticos del Suroeste de la Península Ibérica. Complutum Extra, 2, Madrid.

Blanco GonzÁlez, A. (2008): Tendencias del uso del suelo en el Valle Amblés (Ávila, España). Del Neolítico al Hierro Inicial. Zephyrus, LXII (julio-diciembre): 101-123.

Blanco González, A. (2010a): ¿Nuevos hogares para los emigrantes? Casas y paisajes en el debate sobre el límite entre Cogotas I y el Primer Hierro en el Valle del Duero. Zephyrus, LXVI (julio-diciembre): 155-179.

Blanco GonzÁlez, A. (2010b): La definición del Hierro Antiguo en el castro de Las Cogotas (Cardeñosa, Ávila). Consideraciones sobre algunos materiales del Museo Arqueológico Nacional. Complutum, 21 (1): 123-143.

Blanco GonzÁlez, A. (2011): From huts to "the house": the shift in perceiving home between the Bronze Age and the Early Iron Age in Central Iberia (Spain). Oxford Journal of Archaeology, 30 (4): 393-410.

Blanco González, A.; Fabián, F. (2005): Los orígenes de las comunidades castreñas en el suroeste de la Meseta española: el proceso histórico Bronce Final-Segunda Edad del Hierro. Castro, um lugar para habitar. Colóquio Monte Mozinho 2004 (T. Pires, coord.), Cadernos do Museo, 11, Penafiel: 41-53.

Blázquez, C. (1995): Sobre las cecas celtibéricas de Tamusia y Sekaisa y su relación con Extremadura. Archivo Español de Arqueología, 68: 243-258.

Bocquet-Appel, JP. (ed.) (2008): Recent advances in Paleodemography: Data, Techniques, Pattterns. Springer, Netherlands.

BowsER, B. J. (2000): From pottery to politics: an ethnoarchaeological study of political factionalism, ethnicity and domestic pottery style in the Ecuadorian Amazon. Journal of Archaeological Method and Theory, 7(3): 219-248.

Bradley, R.; Yates, D. (2007): After celtic fields: the social organisation of Iron Age agricultura. The Earlier Iron Age in Britain and the Near Continent (C. Haselgrove, R. Pope, eds.), Oxbow Books, Oxford: 94-102.

Brun, P. (1987): Princes et Princesses de la Celtique. Le Premier Age du Fer (850-450 av. J.C.). Errance, Paris

Buchsenschutz, O. (1988): Oppidum. Dictionnaire de la Préhistoire (A. Leroi-Gourhan, ed.), Paris. 
Burillo Mozota, F. (1998): Los celtíberos. Etnias y estados. Crítica, Barcelona.

CABré, J. (1930): Excavaciones en Las Cogotas. Cardeñosa (Avila). I. El Castro. Memorias de la Junta Superior de Excavaciones y Antigüedades, 110. Madrid.

CABRÉ, J. (1932): Excavaciones en Las Cogotas. Cardeñosa (Avila). II. La Necrópolis. Memorias de la Junta Superior de Excavaciones y Antigüedades, 120. Madrid.

Cabré, J.; CABré, Ma.E.; Molinero, A. (1950): El Castro y la Necrópolis del Hierro Céltico de Chamartín de La Sierra (Ávila). Acta Arqueológica Hispánica, V. Madrid.

Cantalapiedra, R. (2007): Un nuevo verraco en el Arco de San Vicente. Diario de Ávila, 28-29 de noviembre.

Carrobles, J. (2009): Prehistoria de Toledo. El origen de la ciudad. Ediciones Covarrubias, Toledo.

CASTRO, P.V. (1986): Organización espacial y jerarquización social en la necrópolis de Las Cogotas (Ávila). Arqueología Espacial, 9: 127-137.

Chamberlain, A. T. (2006): Demography in Archaeology. Cambridge Manuals in Archaeology, Cambridge.

Chapa, T.; Pereira, J. (2006): Un Vado perdido. El cerro de la Mesa (Alcolea de Tajo, Toledo). Miscelánea en Homenaje a Victoria Cabrera. Zona Arqueológica, 7, vol. II, Museo Arqueológico Regional, Alcalá de Henares: 120-133.

Charro Lobato, Ma .C. (2009): Estudio de los verracos del valle medio del Tajo. Una aproximación desde el paisaje. Actas de las I Jornadas de jóvenes en investigación arqueológica (JIA): Dialogando con la cultura material, Madrid: 329-334.

Charro Lobato, Ma . C.; Cabrera, A. (2011): El yacimiento arqueológico del Cerro de la Mesa y su entorno (Alcolea de Tajo, Toledo). Los vínculos entre el hábitat y el paisaje. Actas del Primer Congreso de Arqueología de Chamartín (Ávila) (J.P. López García, D. Hernández, J. García, eds.), Ediciones de la Ergástula, Madrid: 209-218.

Collis, J. (1984): Oppida. Earliest Towns North of the Alps. Dept. of Prehistory and Archaeology, University of Sheffield.

Collis, J. (2000): Celtic Oppida. A Comparative Study of Thirty City-State Cultures (M. Herman Hansen, ed.), Det Kongelige Danske Videnskabernes Selskab, Historiske-filosofiske Skrifter, 21, Copenhagen: 229-239.

Collis, J. (2008): The vettones in a european context. Arqueología Vettona. La Meseta Occidental en la Edad del Hierro (J. Álvarez-Sanchís, ed.), Zona Arqueológica, 12, Museo Arqueológico Regional, Alcalá de Henares: 62-77.

Cuesta Gómez, F.; Delibes, G.; Esparza, A. (2010): ¿Existe una joyería vaccea? De la Región Vaccea a la Arqueología Vaccea (F. Romero, C. Sanz, eds.), Vaccea Monografías, 4, Valladolid: 397-435.

Cunliffe, B.W. (1990): Before Hillforts. Oxford Journal of Archaeology, 9 (3): 323-336.

CunLIfFe, B.W. (1994): After Hillforts. Oxford Journal of Archaeology, 13 (1): 71-84.

CunlifFe, B.W. (1998): The impact of Rome on Barbarian Society, 140 BC-AD 300. Prehistoric Europe. An Illustrated History (B. Cunliffe, ed.), Oxford University Press, Oxford: 411-446.

Cunliffe, B.W. (2003): The Celts. A Very Short Introduction. Oxford University Press, Oxford.

Delibes, G.; Esparza, A. (1989): Los tesoros prerromanos de la Meseta Norte y la orfebrería celtibérica. El Oro en la España Prerromana, Revista de Arqueología, Madrid: 108-129.

Delibes, G., Esparza, A.; Martín Valls, R. (1996): Los tesoros prerromanos de Arrabalde (Zamora) y la joyería celtibérica, Zamora.

Delibes, G.; Esparza, A.; Martín Valls, R.; Sanz Mínguez, C. (1993): Tesoros celtibéricos de Padilla de Duero". Arqueología vaccea. Estudios sobre el mundo prerromano en la cuenca media del Duero (F. Romero, C. Sanz, Z. Escudero, eds.), Junta de Castilla y León, Valladolid: 397-470.

Díaz-Andreu, M.; Lucy, S.; Babic, S.; Edwards, D.N. (2005): The Archaeology of Identity: Approaches to Gender, Age, Status, Ethnicity and Religion. Routledge, Londres.

Domínguez Monedero, A. (2008): Los vettones en los textos clásicos. Arqueología Vettona. La Meseta Occidental en la Edad del Hierro (J. Álvarez-Sanchís, ed.), Zona Arqueológica, 12, Museo Arqueológico Regional, Alcalá de Henares: 364-379. 
Esparza, A. (1999): Economía de la Meseta prerromana. Studia Historica, $H^{a}$ Antigua, 17: 87-123.

Esparza, A. (2003): Castros con piedras hincadas del oeste de la Meseta y sus aledaños. Chevaux de frise i fortificació en la primera edat del ferro europea (N. Alonso, E. Junyent, A. Lafuente, J.B. López, coords.), Lleida: $155-178$.

Esparza, A.; Blanco GonzÁlez, A. (2008): El solar de Vettonia, antes de los vettones. Arqueología Vettona. La Meseta Occidental en la Edad del Hierro (J. Álvarez-Sanchís, ed.), Zona Arqueológica, 12, Museo Arqueológico Regional, Alcalá de Henares: 214-231.

Fabián, J. F. (1999): La transición del Bronce Final al Hierro I en el sur de la Meseta Norte. Nuevos datos para su sistematización. Trabajos de Prehistoria, 56.2: 161-180.

Fabián, J. F. (2005a): Castro de Las Paredejas (Medinilla, Ávila). Cuadernos de Patrimonio Abulense, 7 , Institución Gran Duque de Alba, Ávila.

Fabián, J.F. (2005b): Castro de La Mesa de Miranda. Chamartín, Ávila. Cuadernos de Patrimonio Abulense, 2, Institución Gran Duque de Alba, Ávila.

FABIÁN, J.F. (2007): Los orígenes de la ciudad de Ávila y la época antigua. Aportaciones de la arqueología al esclarecimiento de las cuestiones históricas previas a la etapa medieval. Avila en el tiempo. Homenaje al profesor Ángel Barrios, Vol. I, Institución Gran Duque de Alba, Diputación Provincial de Ávila: 83-111.

Fernández Gómez, F. (1995): La Edad del Hierro. Historia de Ávila I. Prehistoria e Historia Antigua (M. Mariné, coord.), Institución Gran Duque de Alba, Ávila: 105-269.

FernÁndez Gómez (1997): La Necrópolis de la Edad del Hierro de "El Raso" (Candeleda. Ávila). "Las Guijas, B". Memorias, 4, Arqueología en Castilla y León, Valladolid.

FernÁNDEZ Gómez, F. (2008): Anatomía de un castro vettón. El Raso de Candeleda. Arqueología Vettona. La Meseta occidental en la Edad del Hierro (J. Álvarez-Sanchís, ed.), Zona Arqueológica, 12, Museo Arqueológico Regional, Alcalá de Henares: 182-200.

FernÁndez Götz, M. A. (2008): La construcción arqueológica de la etnicidad. Editorial Toxosoutos, Serie Keltia, 42, A Coruña.

FichtL, S. (2005) : La ville celtique (les oppida de 150 av. J.-C. à 15 ap. J.-C.). Errante, Paris.

Gebhard, R. (1991): Die Fibeln aus dem Oppidum von Manching. Franz Steiner, Stuttgart.

Gillani, G.; Santonja, M. (eds.) (2007): Arqueología en la Vía de la Plata (Salamanca). Ediciones de la Fundación Premysa, Colección gentes y paisajes, Salamanca.

GómEz, F. (2010): Descubren restos de un castro celtibérico en pleno centro de Salamanca. www.Elnortedecastilla.es $(24 / 12 / 2010)$.

GonzÁlez Ruibal, A. (2003): La experiencia del otro. Una introducción a la etnoarqueología. Akal. Madrid.

GonzÁlez-TABlAs, F. J. (2008): La casa vettona. Actuaciones recientes en el castro de La Mesa de Miranda (Chamartín de la Sierra, Avila). Arqueología Vettona. La Meseta Occidental en la Edad del Hierro (J. Álvarez-Sanchís, ed.), Zona Arqueológica, 12, Museo Arqueológico Regional, Alcalá de Henares: 202211.

GonzÁlez Tablas, F. J. (2009): Las murallas de Las Cogotas y La Mesa de Miranda. Apuntes a la arquitectura defensiva de los vettones. Zephyrus, LXIV: 63-79.

GutiérRez Robledo, J.L. (1999): Un verraco en las murallas. Descubrir el Arte, 8: 112-113.

Haselgrove, C. (dir.) (2006): Celtes et Gaulois. L'Archéologie face à L'Histoire. Les Mutations de la fin de l'âge du Fer. Actes de la table ronde de Cambridge, Collection Bibracte- 12/4, Glux-en-Glenne.

Hassan, F. A. (1981): Demographic Archaeology. Academic Press, Nueva York.

Hernández, F. (1989): Excavaciones en el Castro de Villasviejas del Tamuja (Botija, Cáceres). Editoral Regional de Extremadura, Mérida.

Hernández, F.; Galán, E.; Martín Bravo, A. (2008): La necrópolis prerromana de El Romazal I (Plasenzuela, Cáceres). Arqueología Vettona. La Meseta Occidental en la Edad del Hierro (J. Álvarez-Sanchís, ed.), Zona Arqueológica, 12, Museo Arqueológico Regional, Alcalá de Henares: 222-236.

HernÁNDEZ SÁnchez, D. (2011): El poblamiento castreño del occidente salmantino. Los vínculos entre el hábitat y el paisaje. Actas del Primer Congreso de Arqueología de Chamartín (Ávila) (J.P. López García, D. Hernández, J. García, eds.), Ediciones de la Ergástula, Madrid: 139-148. 
HiLl, J. D. (2006): Are we any closer to understanding how later Iron Age societies worked (or did not work)? Celtes et Gaulois. L'Archéologie face à L'Histoire. Les Mutations de la fin de l'âge du Fer (C. Haselgrove, dir.), Actes de la table ronde de Cambridge, Collection Bibracte- 12/4, Glux-en-Glenne: 169-179.

Hole, F. (1984): Analysis of structure and design in prehistoric ceramics. World Archaeology, 15 (3): 326-347. Jimeno, A. (2000): El origen del urbanismo en el Alto Duero. Soria Arqueológica, 2: 239-262.

Jimeno, A.; Arlegui, M. (1995): El poblamiento en el Alto Duero. Poblamiento Celtibérico. III Simposio sobre los Celtíberos (F. Burillo Mozota, coord.), Institución Fernando El Católico, Zaragoza: 93-126.

KunTz, W. (1987): La necrópolis de Las Cogotas. Volumen I: Ajuares. Revisión de los materiales de la necrópolis de la Segunda Edad del Hierro en la Cuenca del Duero (España). B.A. R., Int. Series, 344, Oxford.

López García, J.P. (2011): La construcción simbólica de los paisajes. La casa "C" de La Mesa de Miranda y su relación con el entorno. Los vínculos entre el hábitat y el paisaje. Actas del Primer Congreso de Arqueología de Chamartín (Ávila) (J.P. López García, D. Hernández, J. García, eds.), Ediciones de la Ergástula, Madrid: 219-232.

López JimÉnez, O. (2005): Paisajes y estructura social en la Protohistoria del área sudoccidental de la Meseta Norte. Bronce Final y Edad del Hierro en la Península Ibérica. Encuentro de Jóvenes Investigadores 2003 (A. Blanco, C. Cancelo, A. Esparza, eds.), Ediciones Universidad de Salamanca: 336-355.

López Melero, R.; Sánchez Abal, J.L.; García Jiménez, S. (1984): El bronce de Alcántara. Una deditio del 104 a. C. Gerión, 2: 264-323.

López-SÁez, J. A.; Blanco GonzÁlez, A.; López-Merino, L.; Ruiz-Zapata, M. B.; Dorado-Valiño, M.; Pérez-Díaz, S.; Valdeolmillos, A.; Burjachs, F. (2009): Landscape and climatic changes during the end of the Late Prehistory in the Amblés Valley (Ávila, central Spain), from 1200 to $400 \mathrm{cal}$ BC. Rhythms and causalities of the anthropisation dynamic in Europe between 8500 and $2500 \mathrm{cal}$ BP: Sociocultural and/or climatic assumptions (D. Galop, L. Carroza, M. Magny, G. Gilaine, eds.), Quaternary International, 200: 90-101.

López SÁez, J. A.; López Merino, L.; Pérez DíAz, S. (2008): Los vettones y sus paisajes: paleoambiente y paleoeconomía de los castros de Ávila. Arqueología Vettona. La Meseta Occidental en la Edad del Hierro (J. Álvarez-Sanchís, ed.), Zona Arqueológica, 12, Museo Arqueológico Regional, Alcalá de Henares: $140-152$.

Lorrio, A.; Ruiz Zapatero, G. (2005): The Celts in Iberia: an overview. The Celts in the Iberian Peninsula, e-keltoi, Journal of Interdisciplinary Celtic Studies, vol. 6: 167-254.

MACARRo, C. (1999): El primitivo asentamiento de Salmantica: aportaciones al conocimiento de la Cultura del Soto en el valle del Tormes. Memoria de Grado (inédita), Departamento de Prehistoria, Historia Antigua y Arqueología, Universidad de Salamanca.

Mariné, M. (1995): La época romana. Historia de Avila I. Prehistoria e Historia Antigua (M. Mariné, coord.), Institución Gran Duque de Alba, Ávila: 273-327.

Martín Bravo, A. Ma . (1999): Los orígenes de Lusitania. El I milenio a. C. en la Alta Extremadura. Biblioteca Archaeologica Hispana, 2, Real Academia de la Historia, Madrid.

Martín Bravo, A. Ma . (2009): Los castros de la cuenca extremeña del Tajo, bisagra entre lusitanos y vettones. Lusitanos y Vettones. Los pueblos prerromanos en la actual demarcación Beira Baixa - Alto Alentejo Cáceres (P. J. Sanabria, ed.), Memorias, 9, Museo de Cáceres: 147-160.

Martín Valls, R. (1982): La necrópolis del castro de Yecla de Yeltes. Datos arqueológicos y epigráficos para su estudio. Zephyrus, XXXIV-XXXV: 181-201.

Martín Valls, R. (1985): La Segunda Edad de Hierro. Historia de Castilla y León, I. La Prehistoria del valle del Duero, Valladolid.

Martín VALLs, R. (1986-87): La segunda Edad del Hierro: consideraciones sobre su periodización. Actas del Coloquio Internacional sobre la Edad del Hierro en la Meseta Norte. Zephyrus, XXXIX-XL: 59-86.

Martín Valls, R. (1999): La Edad del Hierro. Historia de Salamanca. I. Prehistoria y Edad Antigua (2 $2^{\mathrm{a}}$ ed.) (J.L. Martín, dir.), Centro de Estudios Salmantinos, Salamanca: 123-217.

Martin Valls, R.; Benet, N.; Macarro, C. (1991): Arqueología de Salamanca. Del Paleolítico a la Historia (M. Santonja, coord.), Salamanca: 137-163. 
Martín Valls, R.; Esparza, A. (1992): Génesis y evolución de la Cultura Celtibérica. Paleoetnología de la Península Ibérica (M. Almagro-Gorbea, G. Ruiz Zapatero, eds.), Complutum, 2-3: 259-279.

Martín Valls, R.; Pérez Gómez, P. L. (2004): El verraco de Yecla de Yeltes: consideraciones sobre su interpretación. Zephyrus, LVII: 283-301.

Martín Valls, R.; Pérez Herrero, E. (1976): Las esculturas zoomorfas de Martiherrero (Avila). Boletín del Seminario de Arte y Arqueología, XLII: 67-88.

Martín VAlLs, R.; Romero, F. (2008): Las insculturas del castro de Yecla de Yeltes. Nuevas perspectivas para su estudio. Arqueología Vettona. La Meseta Occidental en la Edad del Hierro (J. Álvarez-Sanchís, ed.), Zona Arqueológica, 12, Museo Arqueológico Regional, Alcalá de Henares: 232-251.

Martínez Lillo, S.; Murillo, J.I. (2003): Últimas actuaciones arqueológicas en las murallas. La Muralla de Ávila (A. Barrios, coord.), Fundación Caja Madrid, Madrid: 268-291.

Misiego, J; Sanz, J.: Marcos, G.; Martín, M: (1998): Un complejo artesanal documentado en la calle Arcediano de Salamanca. Aproximación a la funcionalidad de un sector de la antigua Salmantica. II Congreso de Arqueología Peninsular, IV, Zamora: 195-209.

Neustupny, E. (1983): The Demography of Prehistoric Cemeteries. Památky Archeologické, LXXIV: 7-34.

Ortiz, P.; RodríGuez DíAz, A. (1998): Culturas indígenas y romanización en Extremadura: castros, oppida y recintos ciclópeos. Extremadura Protohistórica: Paleoambiente, Economía y Poblamiento (A. Rodríguez Díaz, coord.), Universidad de Extremadura, Cáceres.

Padilla Fernández, J. J. (2010): Arqueología de la cerámica en la Edad del Hierro: el proceso de producción en el alfar de Las Cogotas (Cardeñosa, Ávila). Trabajo Fin de Máster, Departamento de Prehistoria y Arqueología, Universidad de Granada.

Pérez Gutiérrez, M. (2010): Astronomía en los castros celtas de la provincia de Ávila. Institución Gran Duque de Alba, Diputación Provincial de Ávila.

Quintana, J.; Centeno, I.; Entrecanales, R. R. (2003-2004): El nacimiento de la ciudad de Ávila. Nuevos datos a partir de las cerámicas del Mercado Grande. Boletín del Seminario de Arte y Arqueología, LXIXLXX: 147-177.

Ralston, I.B. M. (2006): Celtic Fortifications. Tempus, Stroud, Gloucestershire.

Ríos GonZÁLEZ, S. (2000): Consideraciones funcionales y tipológicas en torno a los baños castreños del NO. de la Península Ibérica. Gallaecia, 19: 93-124.

Rodríguez Colmenero, A. (1999): O Santuário Rupestre Galaico-Romano de Panóias (Vila Real, Portugal). Deorum Témenh (I), Vila Real.

RODRÍGUEZ HERNÁNDEZ, J. (2009): El lenguaje de las piedras: aproximación arqueológica a la cantería entre los Vettones. Trabajo de Investigación de Doctorado, presentado en el Departamento de Prehistoria, Facultad de Geografía e Historia de la Universidad Complutense. (Inédito).

Rodríguez Morales, J. (2009): Una nueva tésera con leyenda "Avilaca". Formas de integración en el mundo romano (G. Bravo, R. González Salinero, eds.), Actas del VI Coloquio de la Asociación Interdisciplinar de Estudios Romanos, Signifer Libros, Madrid.

RoldÁn Hervás, J. M. (1968-69): Fuentes antiguas para el estudio de los Vettones. Zephyrus, XIX-XX: 73-106.

Rowlett, R. M. (1989): Detecting political units in archaeology - an Iron Age example. Archaeological Approaches to Cultural Identity (S. J. Shennan, ed.), Unwin Hyman, Londres: 219-230.

Ruiz Entrecanales, R. (2005): Guía Castro de Las Cogotas (Cardeñosa, Ávila). Cuadernos de Patrimonio Abulense, Institución Gran Duque de Alba, Diputación de Ávila.

Ruzz-GÁlvez, M. (1992): La novia vendida: orfebrería, herencia y agricultura en la protohistoria de la Península Ibérica. SPAL, 1: 219-251.

Ruiz Zapatero, G. (2003): Las fortificaciones de la Primera Edad del Hierro en la Europa templada. Chevaux de frise i fortificació en la primera edat del ferro europea (N. Alonso, E. Junyent, A. Lafuente, J.B. López, coords.), Lleida: 13-34.

Ruz Zapatero, G. (2005): Castro de Ulaca. Solosancho, Ávila. Cuadernos de Patrimonio Abulense, 3, Institución Gran Duque de Alba, Ávila. 
Ruiz Zapatero, G. (2007): Imágenes de la sociedad prerromana: Vettones. Ecos del Mediterráneo. El mundo ibérico y la cultura vettona (M. Barril, E. Galán, coords.), Institución Gran Duque de Alba, Ávila: 67-72.

Ruiz Zapatero, G. (2009): Etnicidad protohistórica y arqueología: límites y posibilidades. Arqueología Espacial: Identidades. Homenaje a $M^{a}$ Dolores Fernández-Posse (I. Sastre, coord.), Arqueología Espacial, 27, Teruel: 13-27.

Ruiz Zapatero, G. (2010): Arqueología del proceso de etnogénesis en la Meseta prerromana: los vacceos. De la Región Vaccea a la Arqueología Vaccea (F. Romero, C. Sanz, eds.), Vaccea Monografías, 4, Valladolid: 37-63.

Ruiz Zapatero, G.; Álvarez-Sanchís, J. R. (1995): Las Cogotas: Oppida and the Roots of Urbanism in the Spanish Meseta. Social complexity and the Development of Towns in Iberia: from the Copper Age to the second century $A D$ (B. Cunliffe, S. J. Keay, eds.), Proceedings of the British Academy, 86, Londres: 209-236.

Ruiz Zapatero, G.; ÁlvareZ-SAnchís, J. R. (2002): Etnicidad y Arqueología: tras la identidad de los vettones. Spal, 11: 253-275.

Ruiz Zapatero, G.; Álvarez-Sanchís, J. R. (2008): Los verracos y los vettones. Arqueología Vettona. La Meseta Occidental en la Edad del Hierro (J. Álvarez-Sanchís, ed.), Zona Arqueológica, 12. Museo Arqueológico Regional, Alcalá de Henares: 214-231.

Sacristán, J. D. (1986): La Edad del Hierro en el valle medio del Duero. Rauda (Roa, Burgos). Junta de Castilla y León y Universidad de Valladolid, Valladolid.

Sacristán, J. D.; SAn Miguel, L. C.; Barrio, J.; Celis, J., (1995): El poblamiento de época celtibérica en la cuenca media del Duero. Poblamiento Celtibérico. III Simposio sobre los Celtíberos (F. Burillo Mozota, coord.), Institución Fernando el Católico, Zaragoza: 337-367.

Salas Lopes, N. (2008): El alfar de la Segunda Edad del Hierro de Las Cogotas (Cardeñosa, Ávila). Trabajo de Investigación de Doctorado, Departamento de Prehistoria, Universidad Complutense de Madrid.

SALINAS, M. (1992-93): El poblamiento rural antiguo de la provincia de Salamanca: Modelos e implicaciones históricas. El medio rural en Lusitania Romana. Formas de hábitat y ocupación del suelo (J.G. Gorges, M. Salinas, eds.), Studia Historica, Historia Antigua, X-XI: 177-188.

Salinas, M. (2001): Los vettones. Indigenismo y romanización en el occidente de la Meseta. Ediciones Universidad de Salamanca.

San Miguel Maté, L. C. (1993): El poblamiento de la Edad del Hierro al occidente del valle medio del Duero. Arqueología vaccea. Estudios sobre el mundo prerromano en la cuenca media del Duero (F. Romero, C. Sanz, Z. Escudero, eds.), Junta de Castilla y León, Valladolid: 21-65.

Sanz, C.; Velasco, J.; Centeno, I.; Gallardo, M. A.; Del Olmo, J. (2003): Pintia: nacimiento y desarrollo de un oppidum vacceo-romano. Pintia. Un oppidum en los confines orientales de la región vaccea (C. Sanz, J. Velasco, eds.), Universidad de Valladolid: 45-65.

Sherrat, A. (1993): What would a Bronze-Age World System look like? Relations between temperate Europe and the Mediterranean in Later Prehistory. Journal of European Archaeology, 2: 1-56.

Wels-Weyrauch, U. (1994): Im Grab erhalten, im Leben getragen - Tracht und Schmuck der Frau. Bronzezeit in Deutschland (A. Jockenhövel, W. Kubach, ed.), Konrad Theiss Verlag, Stuttgart: 59-64.

Wells, P. S. (1984): Farms, Villages and Cities. Comerce and urban origins in Late Prehistoric Europe. Cornell University Press.

Wells, P. S. (1998): Identity and Material Culture in the Later Prehistory of Central Europe. Journal of Archaeological Research, 6 (3): 239-298.

Wells, P.S. (2002): The Iron Age. European Prehistory. A survey (S. Milisauskas, ed.), Kluwer Academic, Plenum Publishers, Nueva York. 